\title{
Article \\ Effect of Attractants and Micronutrient Biofortification on the Yield and Quality of Red Clover (Trifolium pratense L.) Seeds
}

\author{
Anna Przybylska ${ }^{1}$, Marek Ćwintal ${ }^{2}$, Piotr Pszczółkowski ${ }^{3}$ and Barbara Sawicka ${ }^{2, *(1)}$ \\ 1 Agricultural Enterprise “Osowiec", Osowiec 1 str., 22-107 Sawin, Poland; annaprzybylska-lublin@wp.pl \\ 2 Department of Plant Production Technology and Commodities Science, University of Life Science in Lublin, \\ Akademicka 15, str., 20-950 Lublin, Poland; helena.cwintal@up.lublin.pl \\ 3 Experimental Station for Cultivar Assessment of Central Crop Research Centre, Uhnin, \\ 21-211 Dębowa Kłoda, Poland; P.Pszczolkowski.inspektor@coboru.gov.pl \\ * Correspondence: barbara.sawicka@up.lublin.pl; Tel.: +48-81-445-67-87
}

Citation: Przybylska, A.; Ćwintal, M.; Pszczółkowski, P.; Sawicka, B.

Effect of Attractants and

Micronutrient Biofortification on the Yield and Quality of Red Clover (Trifolium pratense L.) Seeds. Agronomy 2021, 11, 152. https://doi.org/ 10.3390/agronomy11010152

Received: 27 November 2020 Accepted: 11 January 2021 Published: 14 January 2021

Publisher's Note: MDPI stays neutral with regard to jurisdictional clai$\mathrm{ms}$ in published maps and institutional affiliations.

Copyright: (C) 2021 by the authors. Licensee MDPI, Basel, Switzerland. This article is an open access article distributed under the terms and conditions of the Creative Commons Attribution (CC BY) license (https:// creativecommons.org/licenses/by/ $4.0 /)$.

\begin{abstract}
The aim of the research was to develop an innovative technique in the seed production of red clover. The research was carried out in 2013-2016, in Felin $\left(51^{\circ} 22^{\prime} \mathrm{N}, 22^{\circ} 65^{\prime} \mathrm{E}\right)$, in a dependent arrangement (split-split-plot) in four replications. The first order factor was the use of an attractant: (1) control object, with pure water spraying, (2) attractant used in the $60 \mathrm{BBCH}$ phase, (3) attractant applied twice-in the 60 and 65 phase, in the $\mathrm{BBCH}$ scale. The factor of the second order was fertilization: (a) standard object with PK fertilization; (b) fertilization with microelements (B + Mo) against the background of constant PK fertilization. The use of attractant 'Pollinus' preparation in the cultivation of red clover, both once and twice, in the form of spraying on plants, contributed to an increase in the seed yield, number of heads, share of seeds in the head, thousand seeds weight, and seed germination capacity, compared to the control object. Elements of the red clover yield structure achieved more favorable values with foliar feeding $(\mathrm{B}+\mathrm{Mo})$ compared to the standard one. Under the influence of plant biofortification with boron and molybdenum, the number of seeds infected with fungal pathogens and abnormally germinating decreased.
\end{abstract}

Keywords: clover for seeds; Pollinus; micronutrient fertilization; seed yield; MTS; germination capacity; germination energy; seed hardness

\section{Introduction}

Red clover (Trifolium pratense L.) is a multifunctional species. It is a nutritious plant, rich in valuable nutrients, a valuable source of fodder for ruminants, pigs and poultry in the form of green forage, hay, silage or dried, and provides forage on the farm throughout the year, and is also the valuable medicinal plant. The cultivation of red clover makes it possible to obtain high yields of valuable protein while reducing the consumption of nitrogen fertilizers to a minimum, which results from the ability to synthesize atmospheric nitrogen thanks to the symbiosis of roots with nodule bacteria of the genus Rhizobium. The outlays for the cultivation of this species are much lower than other fodder crops [1-3]. In Poland, red clover with an area of over 42,000 hectares in 2019 is the second most popular perennial fodder plant of the Fabaceae family after alfalfa. Red clover cohabitates with papillary bacteria and can bind biologically up to $200 \mathrm{~kg} \cdot \mathrm{N} \cdot \mathrm{ha}{ }^{-1}$. The $200 \mathrm{~kg} \cdot \mathrm{N}$ produced in the Haber-Bosch process is associated with the emission of about $400 \mathrm{~kg}$ of $\mathrm{CO}_{2}$ into the atmosphere. Hence, legumes can reduce the negative effects of climate change [4]. In recent years, the interest in the cultivation of red clover has been increasing, and thus the demand for seed material of this species. The production of seeds from certified red clover plantations is described as insufficient [4,5]. Therefore, a very important issue is the seed production of this species. In order to encourage pollinating insects to fly red clover various methods of attracting them are used. Substances attracting insects, the so-called attractants are used to increase the effectiveness of pollination. Attractants are agents of 
any nature with a luring effect, increasing sexual attractiveness, and attracting species that pollinate flowers. Many substances have been tested as honeybee attractants [6-11]. The attractiveness of honeybee pheromones was assessed, including pheromone workers and queen mandible pheromone [12-14]. Naik et al. [10,11] assessed the effectiveness of pheromone and plant attractants in experimental conditions. Therefore, studies were carried out to evaluate the attractant for bees "Pollinus" in order to increase the productivity of red clover. Thanks to the use of attractants, it is possible to increase the attractiveness of flowers in an effective way and contribute to the increase in the work efficiency of bees and other pollinating insects, and consequently, the efficiency of seed plantations can be increased $[10,12]$. Another factor that can increase the yield of seeds and improve their quality is fertilization, including fertilization with microelements [4,9]. The choice of boron and molybdenum in the fertilization of red clover, in the experiment, was dictated by the low abundance of these microelements in soils in Poland. The content of boron in soils in Poland is very low, as the abundance of this element in over $90 \%$ of soils ranges from 0.4 to $0.8 \mathrm{mg} / 100 \mathrm{~g}$ of soil. A strong boron deficiency in the substrate leads to disturbances in the development of the hair zone of the red clover root system, which reduces the plant's ability to absorb water and nutrients. Moreover, boron deficiency causes disturbances in pollen and ovary formation, which worsens flower production, flowering, pollen volatility, and fruit setting, and consequently significantly reduces the amount of seed yield. In addition, the level of boron available to red clover (Trifolium pratense L.) can affect nectar production, seed yield, and germination. In the Lublin region, where research on red clover was carried out, soils with a deficiency of molybdenum can be found relatively often. Bad abundance in assimilable molybdenum is shown by approx. $40 \%$ of the examined brown soils and $25 \%$ of alluvial sediments, while the deficiency of molybdenum in rendzinas is less frequent. It is related to the reaction of soils [4,5]. Determining optimal agrotechnical recommendations for red clover is difficult, and at the same time there are no scientific studies on the influence of agrotechnical factors on the yield and quality of red clover seeds. Hence, research was undertaken to develop an innovative technology of seed production of red clover, to understand the relationship between the use of an attractant, fertilization with microelements and the date of seed harvest, as well as to learn about its yield and quality characteristics. It was assumed that the use of an attractant would result in an increase in the yield of red clover seeds through greater seed setting in the inflorescence, which is the main element in the structure of the clover yield. It was assumed that the application of fertilization with microelements will increase the plant density, the number of heads, the number of pods and their filling, increase the weight of 1000 seeds, and thus increase the seed yield and improve their quality. The intention of the research was also to indicate the optimal date of harvesting red clover for seeds. The study verified an alternative hypothesis, which assumes that the use of an attractant and foliar fertilization with boron and molybdenum have a beneficial effect on the seed yield and their quality indicators in the seed production of legumes in the global value chain, against the null hypothesis that there is no difference between attractant and foliar fertilization $(\mathrm{B}+\mathrm{Mo})$ applied. The answer to the hypothesis and research issues are the results of a field experiment carried out in 2013-2016 with red clover grown for seeds.

\section{Material and Methods}

In the years 2013-2016, a field experiment was carried out at the Experimental Farm in Felin $\left(51^{\circ} 22^{\prime} \mathrm{N}, 22^{\circ} 65^{\prime}, \mathrm{EH}=183 \mathrm{~m}\right.$ above sea level), on a soil made of a sandy loam. The experiment was carried out using the random blocks method in a dependent pattern, split-plot design, in four replications. The first order factor was the use of the attractant: (1) control object, without attractant only with pure water spraying, (2) attractant used in $60 \mathrm{BBCH}$ phase, (3) attractant applied twice-in 60 and 65 of the phase of $\mathrm{BBCH}$ scale; the second order factor was fertilization: (a) standard object with PK fertilization; (b) fertilization with microelements $(\mathrm{B}+\mathrm{Mo})$ against the background of constant PK fertilization. The area of plots at the establishment of the experiment was $81 \mathrm{~m}^{2}$, and for 
the harvest it was $27 \mathrm{~m}^{2}$. The object of the research was the Polish variety of the diploid red clover 'Dajana'. This variety is characterized by very good fertility, good winter hardiness, fast regrowth after mowing, high yield of green and dry matter, and medium lodging resistance. The attractant was the 'Pollinus' preparation with significant aromatic qualities, attracting bees. It consists of aromatic compounds of plant origin (geraniol, citral, anethole, linalool). 'Pollinus' is safe for humans and animals, also for predatory and parasitic insects. It also does not cause any negative effects on plants $[15,16]$.

\subsection{Field Research}

A field experiment was carried out in 2013-2016 in Felin on the experimental fields of the University of Life Sciences in Lublin. The forecrop of red clover was potato. In autumn, the field was cultivated (winter plowing) and phosphorus-potassium fertilization at the same level (35 kg.P.ha ${ }^{-1}$ and $66.4 \mathrm{~kg} \cdot \mathrm{K} \cdot \mathrm{ha}{ }^{-1}$ ) was applied, which was determined on the basis of soil fertility. In the spring, the field was prepared for sowing: first the field was levelled and then was harrowed with a medium harrow, and then with a light harrow. In the first decade of April, spring barley was sown first-in the amount of $120 \mathrm{~kg} \cdot \mathrm{ha}^{-1}$ at a spacing of $12 \mathrm{~cm}$, and the red clover in the amount of $8 \mathrm{~kg} \cdot \mathrm{ha}^{-1}$ was sown one day later.

\subsubsection{Characteristics of the Protective Plant}

The experiment was laid out in the fall, each year preparing the substrate and applying appropriate fertilization. The crop that preceded the clover in the crop rotation, in all the years of experiments, was potato. The six-field crop rotation in the experimental field consisted of the following cells: barley with clover under sown, clover, rye, soybean, wheat, potato (Table 1).

Table 1. Plants in rotation (2013-2016).

\begin{tabular}{|c|c|c|c|c|c|c|}
\hline \multirow{2}{*}{ Specification } & \multicolumn{6}{|c|}{ Years } \\
\hline & 2013 & 2014 & 2015 & 2016 & 2017 & 2018 \\
\hline $\begin{array}{l}\text { Preparation of the } \\
\text { Experiment (2013) }\end{array}$ & $\begin{array}{l}\text { Barley with } \\
\text { under sown } \\
\text { red clover }\end{array}$ & Red clover & rye & soy & wheat & potato \\
\hline $\begin{array}{l}\text { 1. year of experience (2014) } \\
\text { (clover under sown - stubble) } \\
+ \text { setting up a new } \\
\text { experience }\end{array}$ & potato & $\begin{array}{l}\text { Barley with } \\
\text { under sown } \\
\text { red clover }\end{array}$ & Red clover & rye & soy & wheat \\
\hline $\begin{array}{l}\text { 2. year of experience (2015) } \\
\text { full use ( } 3 \text { swaths) }+ \\
\text { obtaining the abrasive from } \\
\text { a new experience }\end{array}$ & wheat & potato & $\begin{array}{l}\text { Barley with } \\
\text { under sown } \\
\text { red clover }\end{array}$ & Red clover & rye & soy \\
\hline $\begin{array}{l}\text { 3. year of experience (2016) } \\
\text { (full year of use - } 3 \text { swaths) }\end{array}$ & soy & wheat & potato & $\begin{array}{l}\text { Barley with } \\
\text { under sown } \\
\text { red clover }\end{array}$ & Red clover & rye \\
\hline
\end{tabular}

Source: Own research.

In spring, after soil preparation, barley (cultivar 'Atico') was sown in the amount of $120 \mathrm{~kg} \cdot \mathrm{ha}^{-1}$. In each year of the experiment, barley was sown in beginning of the second decade of April (11 April 2013, 10 April 2014, and 13 April 2015). Sowing seeds were treated with Super Homai 70 DS (S.A.-35\% thiophanate methyl $+20 \%$ thiram $+15 \%$ diazinone-insecticide), and the 'Nitragin' bacterial vaccine (Biofood s.c., Wałcz, Poland) was applied on the day of sowing. The seeds of Trifolium pratense treated with Nitragin were sown one day later than barley, in the amount of $8 \mathrm{~kg} \cdot \mathrm{ha}^{-1}$ in the first half of April (12 April 2013; 11 April 2014, and 14 April 2015).

The variety of spring barley 'Atico' is an early forage variety, with good fertility and quite high resistance to lodging. It is characterized by moderate resistance to mildew, black 
spot, and net blotch, and quite low resistance to barley rust [17]. Plant emergence was determined about 10 days after sowing. Red clover emergence values were determined in spring, after winter and during barley harvesting.

\subsubsection{Techniques of Attractant Application and Foliar Fertilization}

The attractant 'Pollinus' was used in the dose of $1 \mathrm{dm} \cdot \mathrm{ha}^{-1}$ in the morning hours as an aqueous solution in $300 \mathrm{dm}^{3} \cdot \mathrm{ha}^{-1}$. The attractant application technique was as follows:

Control object-no attractant, with spraying a clean water the plants;

A1-application of an attractant in the plant flowering stage (BBCH 60);

A2-double use of attractant: in 60 and $65 \mathrm{BBCH}$ phase.

Technique of fertilization with microelements:

Standard fertilization, with phosphorus-potassium fertilizers, in the amount of $35 \mathrm{~kg} \cdot \mathrm{P}$ and $66.4 \mathrm{~kg} \cdot \mathrm{K} \cdot \mathrm{ha}^{-1}$, was applied in early spring, under cultivator, without spraying with microelements, but with spraying of clean water $\left(300 \mathrm{dm}^{3}\right.$ of water, ha $\left.{ }^{-1}\right)$; foliar fertilization was applied to the leaf rosette of seed growth: $\mathrm{B}-0.35\left(\mathrm{~kg} \cdot \mathrm{ha}^{-1}\right) ; \mathrm{Mo}-0.015\left(\mathrm{~kg} \cdot \mathrm{ha}{ }^{-1}\right)$; in the form of fertilizers 'Borovit' and 'Molybdenite', against the background of uniform of PK fertilization ( $35 \mathrm{~kg} \cdot \mathrm{P}$ and $66.4 \mathrm{~kg} \mathrm{~K} \cdot \mathrm{ha}^{-1}$ ). The micronutrient fertilizers were applied as foliar application, diluted in $300 \mathrm{dm}^{3}$ of water ha ${ }^{-1}$.

Foliar fertilization (B + Mo) was applied in the second seed of cut, when the leaves after the first cut covered the inter-rows (BBCH 25) and at the beginning of plants flowering (BBCH 60). Boron was used in the form of Intermag Borvit 1 L Np029 fertilizer, and molybdenum - in the form of Molybdenite WE $5 \mathrm{~L}$, in the form of an aqueous solution prepared from the above-mentioned preparations. Boron (B) supplied in the fertilizer Borvit $1 \mathrm{~L} \mathrm{Np029}$ is absorbed and moved faster by plants than boron supplied to plants in other forms. Molybdenite WE is a foliar fertilizer. It prevents the occurrence and effectively eliminates the deficiency of molybdenum in plants, which occur especially in soils with unregulated $\mathrm{pH}$ ( $\mathrm{pH}$ below 5.5). Ingredients content [\% by weight]: molybdenum (Mo) 3.0 soluble in water ( $33 \mathrm{~g}$ Mo in $1 \mathrm{dm}^{-3}$ of fertilizer). Foliar fertilizers were applied according to manufacturers' recommendations, in the afternoon and on cloudy days. A battery sprayer was used to perform the treatments, equipped with a flat-fan sprayer with a flow rate of $0.35-0.65 \mathrm{dm} \cdot \mathrm{min}^{-1}$ and a pressure of $0.1-0.2 \mathrm{MPa}$.

\subsection{Plantation Management}

Decisions to perform plant protection treatments were made on the basis of monitoring the occurrence of harmful organisms, taking into account their economic harmfulness. When selecting plant protection products, their selectivity was taken into account and their use was limited to the necessary minimum, by reducing both the doses and the number of treatments. Cultivation treatments were carried out in accordance with the principles of good agricultural practice. Chemical plant protection agents were used to control pests: against weeds and pests, and the doses, dates of application, and choice of preparations were in line with the recommendations of the Institute of Agricultural and Food Research Institute [17] (Table 2).

The beginning of red clover vegetation in the second year of use was recorded in the second or third decade of March. In April, frosts, as well as drought, inhibited the growth and development of clover plants. In the third decade of May, the experiments were stepped up. The earliest flowering of clover plants was observed in the second half of June and even in early July. The length of the flowering phase depended on the weather conditions in the research years and was extended when they were unfavorable. Red clover plants bloomed from 13 to 49 days depending on the weather. In dry years, the clover tied few flower shoots. The longest flowering period was recorded in wet 2014 (approx. 7 weeks). Such a long period of flowering of plants resulted mainly from prolonged periods of abundant rainfall and excessive soil moisture. The period of seed formation, i.e., from the end of flowering to full maturity, lasted from 25 to 35 days. 
Table 2. Agrotechnical procedures and equipment used in the experiment (2013-2015).

\begin{tabular}{|c|c|c|c|}
\hline \multicolumn{4}{|c|}{ Autumn 2013-2015 } \\
\hline \multicolumn{4}{|c|}{$\begin{array}{l}\text { Cultivation } \\
\text { Winter plowing to a depth of about } 27 \mathrm{~cm}\end{array}$} \\
\hline \multicolumn{4}{|c|}{ Herbicides } \\
\hline \multicolumn{4}{|c|}{ 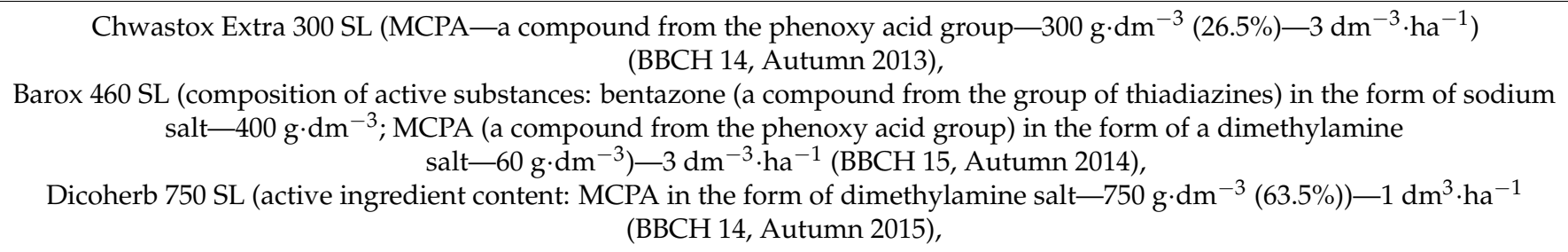 } \\
\hline \multicolumn{4}{|c|}{ Spring 2013-2016 } \\
\hline 2013 & 2014 & 2015 & 2016 \\
\hline $\begin{array}{c}\text { Harrowing } \\
\text { PK fertilization } \\
\text { Dressing the seeds (Nitragina) } \\
\text { Sowing barley seeds } \\
\text { Sowing clover seeds } \\
\text { Spraying with an herbicide } \\
\text { Spraying with insecticide } \\
\text { Harvest }\end{array}$ & $\begin{array}{c}\text { Harrowing } \\
\text { PK fertilization } \\
\text { Seed treatment (Nitragina) } \\
\text { Sowing barley seeds } \\
\text { Sowing clover seeds } \\
\text { Spraying with an herbicide } \\
\text { Spraying with insecticide } \\
\text { Harvest }\end{array}$ & $\begin{array}{c}\text { Harrowing } \\
\text { PK fertilization } \\
\text { Seed treatment (Nitragina) } \\
\text { Sowing barley seeds } \\
\text { Sowing clover seeds } \\
\text { Spraying with an herbicide } \\
\text { Spraying with insecticide } \\
\text { Harvest }\end{array}$ & $\begin{array}{l}\text { Spraying with an herbicide } \\
\text { Spraying with insecticide } \\
\text { Harvest }\end{array}$ \\
\hline \multicolumn{4}{|c|}{ Insecticides and defoliants } \\
\hline \multicolumn{4}{|c|}{$\begin{array}{c}\text { Owadofos } 540 \text { EC }-1 \mathrm{dm}^{-3} \mathrm{ha}^{-1} \text { - phase } 55 \text { on the BBCH scale } \\
\text { Decis } 2.5 \mathrm{EC}\left(0.5 \mathrm{dm}^{-3} \mathrm{ha}^{-1}\right) \\
\text { Patriot } 2.5 \mathrm{EC}\left(0.005 \mathrm{dm}^{-3} \mathrm{ha}^{-1}\right) \\
\text { Reglone } 200 \mathrm{SL}\left(3 \mathrm{dm}^{-3} \cdot \mathrm{ha}^{-1}\right)\end{array}$} \\
\hline
\end{tabular}

Source: Own research.

\subsection{Harvest}

The first cut was harvested at the appropriate stages of red clover development, after prior observation of the vegetation state of the plants. The harvest of clover for green mass was carried out in the second half of May at weekly intervals. Mowing was performed with a petrol bar mower (Fort-working width $1.2 \mathrm{~m}$ with a Lamborghini diesel engine) with a working width of $3 \mathrm{~m}$. Before harvesting, 10 inflorescences were randomly collected from each combination and each replicate to determine the number of pods and seeds in the head, share of set seeds in the head, and mass of 1000 seeds (MTS) (Table 3).

\subsection{Collection and Determination of Soil Samples and Its Physicochemical Properties}

Each year, before starting the experiment, 20 primary soil samples were collected, constituting one aggregate sample weighing about $0.5 \mathrm{~kg}$. Samples collected in this way were used to determine the basic physicochemical and chemical properties of the soil. Soil samples were collected from the humus level $(0-25 \mathrm{~cm})$, after harvesting the crop, from 20 randomly selected places [18,19]. 
Table 3. Swath dates and length of vegetation periods, total rainfall, and average air temperature during vegetation (2014-2016).

\begin{tabular}{|c|c|c|c|c|c|c|c|c|}
\hline \multirow{2}{*}{\multicolumn{2}{|c|}{ Year/Swath }} & \multicolumn{2}{|c|}{ Harvesting of the 1st Cut for Green Mass } & \multicolumn{2}{|c|}{ Harvesting the Second Seed Swath } & \multirow{2}{*}{ 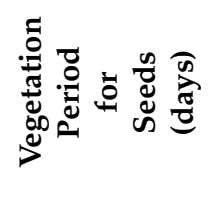 } & \multirow{2}{*}{ 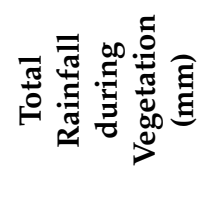 } & \multirow{2}{*}{ 宽 } \\
\hline & & Date & $\begin{array}{l}\text { Development Phase } \\
\text { (Scale BBCH) }\end{array}$ & Date & $\begin{array}{l}\text { Development Phase } \\
\text { (Scale BBCH) }\end{array}$ & & & \\
\hline \multirow{3}{*}{$\stackrel{+}{\stackrel{+}{2}}$} & I & 22. May & 55 & 14 August & 80 & 84 & 258.7 & 19.1 \\
\hline & II & 29 May & 59 & 22 August & 89 & 85 & 219.8 & 19.3 \\
\hline & III & 07 June & 60 & 29 August & 92 & 83 & 252.3 & 18.3 \\
\hline \multirow{3}{*}{$\stackrel{\llcorner}{\stackrel{2}{\sim}}$} & I & 20 May & 55 & 05 August & 80 & 77 & 131.9 & 20.0 \\
\hline & II & 27 May & 59 & 12 August & 89 & 77 & 58.2 & 22.7 \\
\hline & III & 03 June & 60 & 19 August & 92 & 77 & 55.7 & 22.3 \\
\hline \multirow{3}{*}{$\begin{array}{l}0 \\
\stackrel{0}{2}\end{array}$} & I & 23 May & 55 & 10 August & 80 & 79 & 203.4 & 19.5 \\
\hline & II & 30 May & 59 & 16 August & 89 & 78 & 207.2 & 19.4 \\
\hline & III & 06.06 & 60 & 24 August & 92 & 79 & 207.2 & 19.1 \\
\hline
\end{tabular}

Source: Own research. 


\subsection{Determination of the Physicochemical Properties of Soil}

The chemical and physicochemical properties of the soil were determined in the certified laboratory of the Regional Chemical and Agricultural Station in Lublin (Scope of accreditation No. AB 1186) using the following methods:

1. soil granulometric composition was determined by laser diffraction method [19-21];

2. reaction: $\mathrm{pH}$ in $1 \mathrm{M} \mathrm{KCl}$-electrometric [21];

3. organic carbon content-Organic carbon-by the method of Tiurin [22,23];

4. hydrolytic acidity-Hh-by the Kappen method [24,25];

5. content of basic exchangeable cations in $1 \mathrm{M}$ ammonium acetate $\left(\mathrm{Ca}^{+2}, \mathrm{~K}^{+}, \mathrm{Na}^{+}-\right.$by flame photometry [26], $\mathrm{Mg}^{+2}$ content-by ASA method [27];

6. sorption capacity was calculated as the sum of the hydrolytic acidity and the sum of basic cations $(\mathrm{T}=\mathrm{Hh}+\mathrm{S})[24]$;

7. content of $\mathrm{Cu}, \mathrm{Mn}, \mathrm{Zn}, \mathrm{Fe}$ in $1 \mathrm{~mol}$ of $\mathrm{HCl}-$ by the ASA method [28-30];

8. B content-spectrophotometrically with curcumin [31];

9. content of available magnesium using the Schachtschabel method [32];

10. content of assimilable forms of phosphorus and potassium-by the Egner-Riehm method [27,33].

\subsection{Yield Determination and Sampling}

All samples for the evaluation of seeds were collected at three times on days I. and II. sorrow. The inclusion in the research of the first cut of red clover, normally not left for seeds, was intended to better understand the phenomena related to flowering, nectarizing, and pollination of this plant. During the first mowing, the biomass of the red clover was determined and the yield structure $(0.5 \mathrm{~kg}$ samples) was determined $[34,35]$.

\subsection{Methodology for Determining the Characteristics of Seeds}

The quality characteristics of seeds were determined at the Laboratory of the Department of Plant Production Technology and Commodity Science at the University of Life Sciences in Lublin. The laboratory experiment was carried out by the method of complete randomization, in four replications in Petri dishes. The substrate was filter paper soaked in distilled water. The air temperature in the room was $20^{\circ} \mathrm{C}$. For germination, 100 seeds were placed on each plate, in accordance with the recommendations of ISTA [36] and the Regulation of the Minister of Agriculture and Rural Development on detailed requirements for the production and quality of seed [37]. Germination energy was determined in seeds of red clover subjected to germination (after 4 days). Then, 10 days after starting the experiment, the seeds were observed, and the following quality parameters were determined:

1. seed germination capacity $(\%)$,

2. number of normally germinating seeds (production of healthy sprouts, calculated on the 10th day from the start of the experiment),

3. the number of seeds germinating abnormally,

4. number of hard seeds,

5. the number of seeds affected by fungal diseases.

\subsection{Meteorological Conditions}

The characteristics of weather conditions during the growing season of red clover are presented in Tables 4 and 5 and in Figure 1, 2013 was characterized by favorable conditions for growing clover. The sum of precipitation during plant vegetation was $467.1 \mathrm{~mm}$ and was about $50 \%$ higher than the perennial average (Table 4 ).

April, the time of sowing the red clover, which was sown as undersown in spring barley, was generally warm and dry. The heavy rainfall in May provided an optimal start to the initial vegetation of both barley and red clover. The average temperature in May was $2.3{ }^{\circ} \mathrm{C}$ higher than the long-term average. In June, both rainfall and air temperature were also higher than the long-term average. In July, precipitation was higher than the long-term 
average by about $44 \mathrm{~mm}$. On the other hand, August was extremely dry and warm, both due to the Radomski dryness criterion and Sielianinow's hydrothermal coefficient. The rainfall turned out to be about $60 \%$ lower than the average, and the average air temperature was $2{ }^{\circ} \mathrm{C}$ higher than the long-term average. Such a weather pattern in September did not create good conditions for the third cut of clover. According to Radomski's dryness criterion, this year can be considered average, and according to Sielianinov quite wet (Table 5).

Table 4. The sum and distribution of precipitation during the growing season of red clover and the average air temperature in 2013-2016 according to the meteorological station in Felin.

\begin{tabular}{|c|c|c|c|c|c|c|c|c|c|}
\hline \multirow{3}{*}{ હ゙્ } & \multirow{3}{*}{ Month } & \multirow{2}{*}{\multicolumn{3}{|c|}{$\begin{array}{c}\text { Total Rainfall }(\mathrm{mm}) \\
10 \text { Days }\end{array}$}} & \multirow{3}{*}{$\begin{array}{l}\text { Total Rainfall } \\
\text { a Month } \\
\text { (mm) }\end{array}$} & \multirow{2}{*}{\multicolumn{3}{|c|}{$\begin{array}{c}\text { Air Temperature }\left({ }^{\circ} \mathrm{C}\right) \\
10 \text { Days }\end{array}$}} & \multirow{3}{*}{$\begin{array}{l}\text { Average Air } \\
\text { Temperature in the } \\
\text { Month }\left({ }^{\circ} \mathrm{C}\right)\end{array}$} \\
\hline & & & & & & & & & \\
\hline & & 1 & 2 & 3 & & 1 & 2 & 3 & \\
\hline \multirow{7}{*}{$\stackrel{m}{\stackrel{2}{N}}$} & April & 8.9 & 20.3 & 21.9 & 51.1 & 7.0 & 7.5 & 9.8 & 8.1 \\
\hline & May & 39.2 & 28.9 & 33.5 & 101.6 & 11.8 & 14.2 & 17.9 & 15.3 \\
\hline & June & 42.1 & 53.2 & 10.6 & 105.9 & 17.8 & 19.6 & 18.1 & 18.5 \\
\hline & July & 49.3 & 56.7 & 20.1 & 126.1 & 19.6 & 18.4 & 19.6 & 19.2 \\
\hline & August & 0.0 & 9.5 & 8.3 & 17.8 & 20.5 & 19.1 & 18.0 & 19.2 \\
\hline & September & 28.2 & 16.3 & 20.1 & 64.6 & 14.3 & 11.1 & 10.0 & 11.8 \\
\hline & Mean & & & & 467.1 & & & & \\
\hline \multirow{7}{*}{$\underset{\vec{N}}{\vec{d}}$} & April & 3.2 & 15.3 & 26.2 & 44.7 & 7.4 & 7.9 & 14.1 & 9.8 \\
\hline & May & 32.7 & 88.4 & 72.5 & 193.6 & 10.6 & 12.9 & 17.4 & 13.6 \\
\hline & June & 11.2 & 3.0 & 63.9 & 78.1 & 17.4 & 16.0 & 15.4 & 16.3 \\
\hline & July & 14.2 & 38.4 & 30.6 & 83.2 & 19.4 & 19.8 & 21.8 & 20.3 \\
\hline & August & 24.9 & 32.8 & 44.5 & 102.2 & 22.5 & 18.1 & 14.4 & 18.3 \\
\hline & September & 3.2 & 2.7 & 19.3 & 25.2 & 15.3 & 15.4 & 11.2 & 14.0 \\
\hline & Mean & & & & 527.0 & & & & \\
\hline \multirow{7}{*}{ 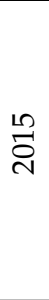 } & April & 12.7 & 2.8 & 25.3 & 40.8 & 4.5 & 8.6 & 13.2 & 8.7 \\
\hline & May & 26.8 & 8.9 & 76.2 & 111.9 & 13.5 & 13.2 & 13.1 & 13.3 \\
\hline & June & 0.8 & 8.1 & 3.2 & 12.1 & 18.6 & 17.7 & 16.8 & 17.7 \\
\hline & July & 9.4 & 23.5 & 10.7 & 43.6 & 23.0 & 20.8 & 21.8 & 21.9 \\
\hline & August & 0.0 & 0.0 & 7.6 & 7.6 & 27.4 & 23.9 & 22.1 & 24.4 \\
\hline & September & 37.7 & 32.2 & 42.8 & 112.7 & 15.4 & 17.6 & 13.1 & 15.3 \\
\hline & Mean & & & & 328.7 & & & & \\
\hline \multirow{7}{*}{$\begin{array}{l}\stackrel{0}{2} \\
\stackrel{2}{2}\end{array}$} & April & 14.0 & 13.6 & 16.4 & 44.0 & 10.7 & 10.6 & 7.9 & 9.7 \\
\hline & May & 14.2 & 21.6 & 2.1 & 37.9 & 13.6 & 12.2 & 19.2 & 15.1 \\
\hline & June & 5.5 & 35.5 & 2.4 & 43.4 & 17.0 & 18.2 & 22.4 & 19.2 \\
\hline & July & 13.7 & 49.8 & 66.2 & 129.7 & 18.9 & 18.7 & 22.0 & 19.9 \\
\hline & August & 28.2 & 5.9 & 37.3 & 71.4 & 19.8 & 16.8 & 19.6 & 18.8 \\
\hline & September & 7.4 & 0.0 & 3.7 & 11.1 & 19.2 & 16.3 & 12.1 & 15.8 \\
\hline & Mean & & & & 337.5 & & & & \\
\hline
\end{tabular}

Source: Own study based on data from the Institute of Water Management and the Felin Meteorological Station.

The year 2014 was the first year of harvesting the red clover and it was abundant in rainfall during the growing season, thus, these conditions could have contributed to the formation of more generative shoots and better regrowth of the first cut. Precipitation in most months was higher than the multiyear average, especially in May (Table 4). This month, according to the Radomski's dryness criterion, should be described as average, and according to the hydrothermal coefficient as extremely wet. It should be assumed that higher values of rainfall and a greater number of days with rainfall could have contributed to the prolongation of clover flowering, while higher daily temperatures and sunshine could shorten this phase. There was a lot of rainfall in May and August. July 2014 was optimal in terms of both rainfall and air temperature, which allowed for good seed 
formation in the 2nd cut. In general, the average air temperatures during the growing season were higher than the average temperatures from many years, except for June. On the other hand, September was very dry, which adversely affected plant growth in the third harvest period. This year, according to Sielianinov's hydrothermal coefficient, can be described as quite wet, and according to Radomski's dryness criterion, as average (Table 5). The average monthly air temperature and precipitation totals are also presented against the background of many years. The years 2014-2016 turned out to be warmer than the long-term average (1981-2010) (Figure 1).

Table 5. Qualification of the vegetation period of plants according to the Sielianinov hydrothermal coefficient and the Radom dryness criterion.

\begin{tabular}{|c|c|c|c|c|}
\hline Year & Month & k * & Ranking of the Month According to Sielianinov & Ranking of the Month According to Radomski \\
\hline \multirow{7}{*}{2013} & April & 2.1 & Wet & Dry \\
\hline & May & 2.1 & Wet & Average \\
\hline & June & 1.9 & Enough wet & Average \\
\hline & July & 2.1 & Wet & Wet \\
\hline & August & 0.3 & Extremely dry & Extremely dry \\
\hline & September & 1.8 & Enough wet & Dry \\
\hline & Mean & 1.7 & Enough we & Average \\
\hline \multirow{7}{*}{2014} & April & 1.5 & Optimum & Very dry \\
\hline & May & 4.6 & Extremely wet & Very wet \\
\hline & June & 1.6 & Optimum & Average \\
\hline & July & 1.3 & Optimum & Average \\
\hline & August & 1.8 & Enough wet & Average \\
\hline & September & 0.6 & very dry & Very dry \\
\hline & Mean & 1.9 & Enough wet & Average \\
\hline \multirow{7}{*}{2015} & April & 1.6 & Optimum & Very dry \\
\hline & May & 2.7 & Very wet & Average \\
\hline & June & 0.2 & Extremely dry & Extremely dry \\
\hline & July & 0.6 & Very dry & Very dry \\
\hline & August & 0.1 & Extremely dry & Extremely dry \\
\hline & September & 2.5 & Wet & Average \\
\hline & Mean & 1.1 & Dry & Dry \\
\hline \multirow{7}{*}{2016} & April & 1.5 & Optimum & Very dry \\
\hline & May & 0.8 & Dry & Very dry \\
\hline & June & 0.8 & Dry & Very dry \\
\hline & July & 2.1 & Wet & Wet \\
\hline & August & 1.2 & Enough dry & Dry \\
\hline & September & 0.2 & Extremely dry & Extremely dry \\
\hline & Mean & 1.1 & Enough dry & Dry \\
\hline
\end{tabular}

Source: Own study according to data from the Institute of Meteorology and Water Management-National Research Institute and the meteorological station in Felin; ${ }^{*}$ Sielianinov hydrothermal coefficient $-K=\frac{P}{0,1 * \Sigma t}$, where: $P$-sum of monthly precipitation, $t-$ sum of average daily air temperatures in a given month; the following ranges of values for the Sielianinov coefficient were adopted: extremely dry $\mathrm{k} \leq 0.4$; very dry $-0.4<\mathrm{k} \leq 0.7$; dry $-0.7<\mathrm{k} \leq 1.0$; quite dry $-1.0<\mathrm{k} \leq 1.3$; optimal- $1.3<\mathrm{k} \leq 1.6$; fairly moist-1.6 $<\mathrm{k} \leq 2.0$; wet $-2.0<\mathrm{k} \leq 2.5$; very wet- $2.5<\mathrm{k} \leq 3.0$; extremely wet- $\mathrm{k}>3.0$; classification of dryness according to Radomski: $<25-$ extremely dry month, 25-49 dry month, 50-74-dry month, 75-125 average month, 126-150 wet month, 151-200—very wet month, $>200$ - extremely wet month wet [38].

The year 2015 was characterized by much higher, average air temperatures and a small amount of rainfall, especially in the months of June-August, which is particularly important for the harvesting of the swath intended for seeds (Table 4). April was optimal in terms of hydrothermal, which was a good prognosis for the emergence and development of plants, while May was characterized by high, average air temperature and high rainfall, higher than the long-term average, which allowed to describe this month as very wet according to the hydrothermal coefficient, and as average-according to Radomski's dryness criterion. June was an extremely dry month, both in terms of Radomski's dryness criterion and 
Sielianinov coefficient. The following month was very dry, and August extremely dry, according to both criteria (Table 5).

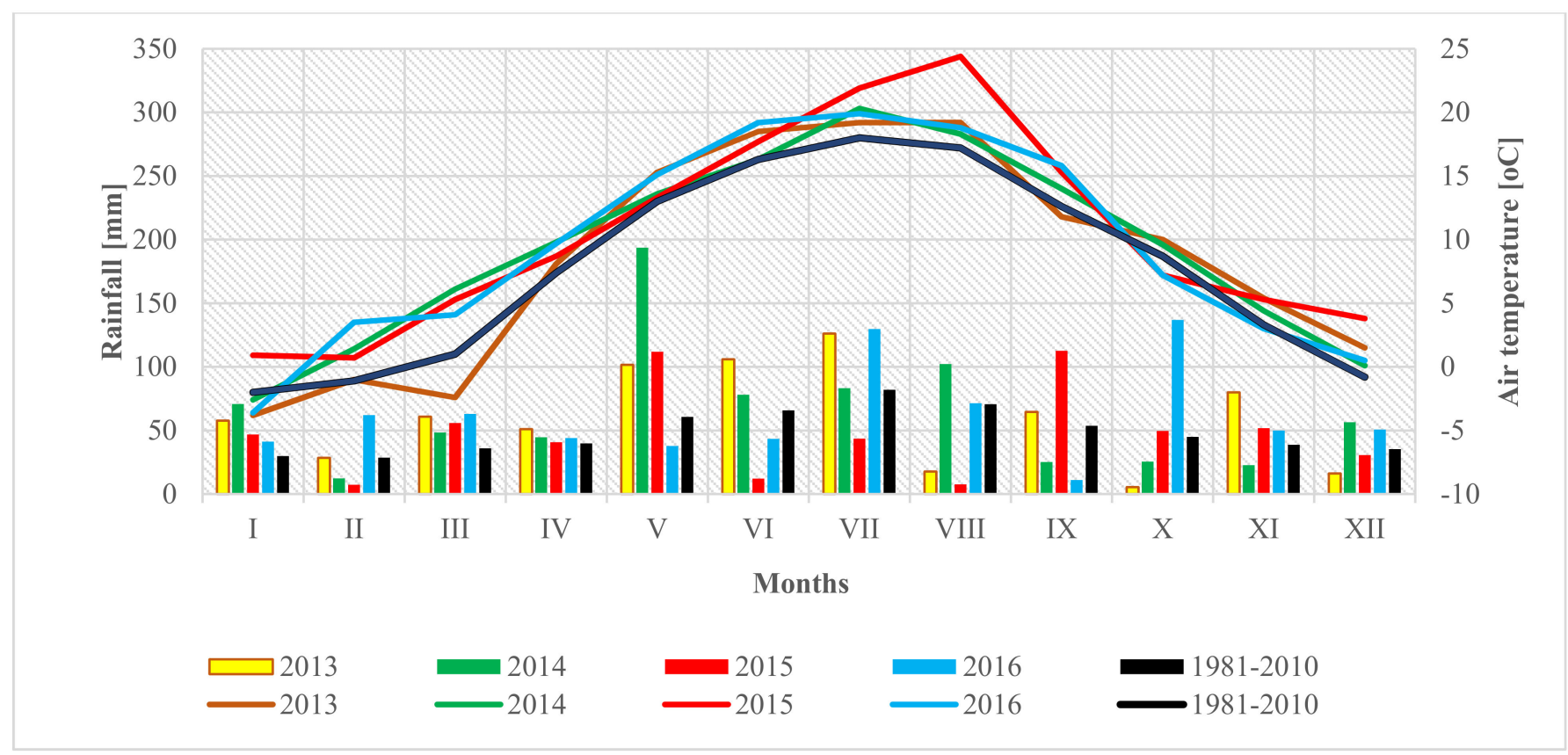

Figure 1. The average air temperature and the course of precipitation during the vegetation period of red clover and plant dormancy in 2013-2016, compared to the long-term average, according to the meteorological station in Felin.

In the last two months, air temperatures were extremely high, which prevented the proper process of plant vegetation and seed maturation. Lack of rainfall and high temperatures contributed to a significant reduction in plant emergence and hindered the vegetation of red clover. September 2015 turned out to be a wet month-according to the hydrothermal coefficient, and the average-according to Radomski's dryness criterion (Table 5), which allowed to obtain a good yield of three clover regrowth and create conditions for plant preparation before winter.

In 2016, the highest air temperatures were recorded throughout the research period, especially in April-May-June, which were decisive for the growth and development of plants in spring (Table 4. Precipitation in April was at an optimal level, but in May and June it was very low, which qualified these months as dry, according to the hydrothermal criterion, and very dry according to the Radomski dryness criterion (Table 5). In July, rainfall was recorded higher than the long-term average by about $40.0 \%$, as over $120 \mathrm{~mm}$ of rainfall fell in the first 10 days of the month, which allowed for a strong regeneration of dry plants. This month was also characterized by a higher average air temperature by $2.9^{\circ} \mathrm{C}$ than the long-term average (Table 4, Figure 1). August turned out to be quite dry according to the hydrothermal criterion and dry according to the Radomski dryness criterion. September was extremely dry, according to both the Sielianinov's and Radomski's hydrothermal coefficients (Table 5).

In general, the years 2013-2014 can be considered optimal, and 2015-2016 as dry or quite dry. Drought during the flowering of clover plants contributed to poor nectarization of flowers, which made them unattractive to pollinating insects, which in turn had an impact on the seed yield. The Sielianinov (k) hydrothermal coefficient [26] was used to determine the dry and very dry periods (Table 5). Droughts are frequent unfavorable weather phenomena resulting mainly from the changeability and transitory nature of Poland's climate. These are one of the most dangerous atmospheric phenomena causing particularly high losses in crops. 


\subsection{Statistical Calculations}

The calculations were made with the SAS Enterprise 4.2 software [39]. Statistical analyzes were based on four-way analysis of variance (ANOVA) models in three-year experiments and three-way analysis of variance models in experiments with one-year data and multiple T-Tukey tests, with the adopted significance level $p=0.05$.

Analysis of variance models with the main effects of the studied factors and their interactions were used, and the detailed analysis focused mainly on the main effects and twofactor interactions [40]. T-Tukey's multiple comparison tests enable detailed comparative analyses of means by isolating statistically homogeneous groups of mean (homogeneous groups), which are determined by the so-called the smallest significant mean differences. In Tukey's tests, they are marked by HSD (Tukey's honest significant difference) [41].

In addition, plots of the compared means for the analyzed factors were made, with attached $95 \%$ confidence intervals (vertical sections). They help to assess confidence in these averages using the variability of the examined characteristics. They show the main and interactive effects.

\section{Explanations for All Tables}

The tables contain the most important elements of the analysis of variance by providing the calculated probabilities (the so-called $p$-value) related to the applied $\mathrm{F}$ test functions (F-Snedecor or Fisher-Snedecor). The calculated $p$ values determine the significance and magnitude of the influence of the examined factors on the differentiation of the results of the analyzed variables by comparing them with the most commonly accepted alpha significance levels $(0.05,0.01, \ldots)$.

For detailed analyses based on multiple T-Tukey (or other) tests, the significance level was $\alpha=0.05$.

Letter indices at the means (significant groups) designate the so-called homogeneous groups (statistically homogeneous). The presence of the same letter index with the means (at least one) means that there is no statistically significant difference between them. The following letter indices $a, b$, etc., define groups of means in ascending order. Additional diagrams do not show large deviations from the normality of the distributions of the analyzed variables.

\section{Results}

\subsection{Soil Conditions}

The field experiment was located on fallow soil created from a dust layer in the Cretaceous era-Haplic Luvisols [42,43], classified as a good wheat complex (class IIIa). This soil heats up very slowly, and after rain it lumps easily and "crusts", with high water storage capacity. Based on the particle size distribution, the soil was classified as a particle size subgroup of clay dust. The leading fraction was the dust fraction (58.09\%), the sand fraction constituted on average $36.41 \%$, and the clay fraction $5.49 \%$ (Table 6 ). The grain size composition allows it to be classified as medium soil $[18,44]$.

Table 6. Soil granulometric composition (\%).

\begin{tabular}{ccccc}
\hline Year & \multicolumn{3}{c}{ Percentage of Fraction Diameter (mm Ø) } & \multicolumn{2}{c}{$\begin{array}{c}\text { Composition } \\
\text { Granulometric } \\
\text { (PTG/USDA) }\end{array}$} \\
\cline { 2 - 5 } & $\mathbf{0 . 5 - 2 . 0}$ & $\mathbf{0 . 5 - 0 . 0 0 2}$ & $<\mathbf{0 . 0 2}$ & $\mathrm{Pyg} / \mathrm{SiL}$ * \\
\hline 2014 & 37.96 & 56.06 & 5.98 & $\mathrm{Pyg} / \mathrm{SiL}$ \\
2015 & 35.49 & 59.21 & 5.20 & $\mathrm{Pyg} / \mathrm{SiL}$ \\
\hline Average & 35.79 & 59.01 & 5.49 & \\
\hline
\end{tabular}

* Pyg—clay dust/SiL—silty loam; source: own study based on the results of the Regional Chemical and Agricultural Station in Lublin. 
The soils tested in 2014 and 2015 were slightly acidic, while in the last year of the study they were acidic. The hydrolytic acidity was not very differentiated and ranged from 22.3 to $22.9 \mathrm{mmol} \mathrm{H}^{+}+\mathrm{kg}^{-1}$. The sum of exchangeable bases tended to decrease with time, from $64.7 \mathrm{mmol} \mathrm{H}^{+}+\mathrm{kg}^{-1}$ in 2014 to $61.1 \mathrm{mmol} \mathrm{H}^{+}+\mathrm{kg}^{-1}$ at the end of the experiment. The degree of saturation of the sorption complex with bases was not high and was in the range of $63.5-64.2 \%$. The humus content in the studied soils was high and ranged from 2.51 to $2.82 \mathrm{~g} \cdot \mathrm{kg}^{-1}$ (Table 7 ) [44].

Table 7. Soil acidity in $\mathrm{KCl}$, hydrolytic acidity, sum of exchangeable bases, and soil sorption capacity.

\begin{tabular}{|c|c|c|c|c|c|}
\hline \multirow[b]{2}{*}{ Year } & \multicolumn{2}{|r|}{ Acidity } & \multirow{2}{*}{$\begin{array}{c}\text { Sum of Replaceable } \\
\left.\text { Alkaline (mmol( }{ }^{+}\right) \\
\left.\text {kg }^{-1}\right)\end{array}$} & \multirow{2}{*}{$\begin{array}{c}\text { Soil Sorption } \\
\text { Capacity }\left(\mathrm{mmol}^{+}\right) \\
\left.\mathrm{kg}^{-1}\right)\end{array}$} & \multirow{2}{*}{$\begin{array}{c}\text { V\% } \\
\text { The Degree of Saturation with } \\
\text { Alkaline Cations }\end{array}$} \\
\hline & $\mathrm{pH} \mathrm{KCl}$ & $\begin{array}{l}\text { Hydrolytic Acidity } \\
\left(\mathrm{mmol} \mathrm{H}^{+} \mathrm{kg}^{-1}\right)\end{array}$ & & & \\
\hline 2014 & 5.7 & 22.9 & 41.5 & 64.7 & 64.1 \\
\hline 2015 & 5.6 & 22.6 & 40.6 & 63.2 & 64.2 \\
\hline 2016 & 5.3 & 22.3 & 38.8 & 61.1 & 63.5 \\
\hline
\end{tabular}

Source: Own study based on the results of the Regional Chemical and Agricultural Station in Lublin.

Taking into account the content of available forms of phosphorus (13.1-18.9 $\mathrm{mg} \cdot 100 \mathrm{~g}^{-1}$ of soil), potassium (16.6-31.7 mg.100 g $\left.\mathrm{g}^{-1}\right)$, and magnesium (4.8-5.1 $\left.\mathrm{mg} \cdot 100 \mathrm{~g}^{-1}\right)$, these soils should be classified as medium- and high-phosphorus-rich, medium- to very highpotassium, and low- to medium-rich in magnesium. The abundance of assimilable micronutrients, soluble in 1 mole of $\mathrm{HCl}$, was in the following ranges: $\mathrm{B} 0.5-0.62 \mathrm{mg} \cdot \mathrm{kg}^{-1}$, $\mathrm{Cu} 1.8-1.9 \mathrm{mg} \cdot \mathrm{kg}^{-1}, 137.8-176.5 \mathrm{mg} \cdot \mathrm{kg}^{-1}, \mathrm{Zn} 6.4-6.8 \mathrm{mg} \cdot \mathrm{kg}^{-1}, \mathrm{Fe} 742-821 \mathrm{mg} \cdot \mathrm{kg}^{-1}$, Mo $0.074-1.45 \mathrm{mg} \cdot \mathrm{kg}^{-1}$ of soil (Table 8 ). These values proved the low abundance of assimilable boron and copper in the soil, low to medium abundance of molybdenum, and the average abundance of assimilable zinc and iron [44].

Table 8. Content of assimilable forms of macro- and micronutrients, humus, and organic carbon in the soil.

\begin{tabular}{|c|c|c|c|c|c|c|c|c|c|c|c|}
\hline \multirow[t]{2}{*}{ Year } & \multicolumn{3}{|c|}{$\begin{array}{c}\text { Content of Assimilable } \\
\text { Macronutrients } \\
\text { (mg } 100 \mathrm{~g}^{-1} \text { of Soil) }\end{array}$} & \multirow[t]{2}{*}{$\begin{array}{l}\text { Humus } \\
\left(\mathrm{g} \cdot \mathrm{kg}^{-1}\right)\end{array}$} & \multirow{2}{*}{$\begin{array}{c}\text { Content of } \\
\text { Organic C } \\
\left(\mathrm{g} \cdot \mathrm{kg}^{-1}\right)\end{array}$} & \multicolumn{6}{|c|}{ The Content of Micronutrients ( $\mathrm{mg} \cdot \mathrm{kg}^{-1}$ of Soil) } \\
\hline & $\mathrm{P}_{2} \mathrm{O}_{5}$ & $\mathrm{~K}_{2} \mathrm{O}$ & $\mathrm{Mg}$ & & & B & $\mathrm{Cu}$ & Mn & Zn & Fe & Mo \\
\hline 2014 & 17.8 & 28.9 & 5.1 & 2.67 & 1.36 & 0.62 & 1.9 & 176.5 & 6.8 & 819 & 0.110 \\
\hline 2015 & 18.9 & 31.7 & 4.8 & 2.82 & 1.45 & 0.60 & 1.8 & 172.4 & 6.4 & 821 & 0.145 \\
\hline 2016 & 13.1 & 16.6 & 4.9 & 2.51 & 1.28 & 0.50 & 1.8 & 137.8 & 6.5 & 742 & 0.074 \\
\hline Average & 16.6 & 25.7 & 4.9 & 2.67 & 1.36 & 0.57 & 1.8 & 162.2 & 6.6 & 794 & 1.08 \\
\hline
\end{tabular}

Source: Own study based on the results of the Regional Chemical and Agricultural Station in Lublin.

\subsection{Seed Yield}

The yield of red clover seeds was significantly differentiated by all the experimental factors (Table 9).

The use of the attractant significantly increased the seed yield by $7.3-12.2 \%$, depending on the number of times the treatment was performed, in relation to the control object. The application of the attractant twice, in the BBCH 60 and BBCH 65 phase, allowed to obtain the highest seed yield; both objects with the attractant application turned out to be homogeneous in terms of the value of this feature. The application of foliar fertilizers with micronutrients $(\mathrm{B}+\mathrm{Mo})$ had a positive effect on the growth and development of plants and resulted in an increase in the seed yield, on average by $20.6 \%$, compared to the standard plant fertilized only with phosphorus-potassium fertilizers. Harvesting dates mostly influenced the yield of clover seeds. Their highest yield was obtained in the second harvest date (after 85 days of vegetation). This value significantly differed from the results obtained in the 1st and 3rd harvest dates. The lowest seed yield was obtained in the last, 
third harvest date with worse flight of pollinating insects. In 2015 and 2016, exceptionally low seed yields were recorded. High air temperature values in the summer months, i.e., the most active vegetation of plants, combined with minimal or no rainfall contributed to poor flowering, poor insect flight, and poor seed setting. The response of plants to harvesting conditions was varied at different times. Only in the wet, sunny year of 2014, significant differences in the value of the seed yield were found between the individual harvest dates. In the remaining years it was observed that between the second and third dates of the set, the differences in the value of this feature were homogeneous with respect to each other. The response of plants to fertilization depended on the growing conditions. In the case of the application of microelements $(B+M o)$, fertilization eliminated the unfavorable weather conditions in the years of the study. The difference in the objects fertilized with foliar micronutrient fertilizers between the second and the last year of the study was insignificant, and the value of the seed yield turned out to be homogeneous. However, the interaction of microelement fertilization and attractant application was not found (Table 9).

Table 9. Effect of attractant application, foliar fertilization, harvest date, and years on the yield of red clover seeds $\left(\mathrm{kg} \cdot \mathrm{ha}^{-1}\right)$.

\begin{tabular}{|c|c|c|c|c|c|}
\hline \multirow{2}{*}{\multicolumn{2}{|c|}{ Experiment Factors }} & \multicolumn{3}{|c|}{ Years } & \multirow{2}{*}{$\bar{x}$} \\
\hline & & 2014 & 2015 & 2016 & \\
\hline \multirow{3}{*}{ Attractant * } & Control object & $1096.3^{a}$ & $530.2^{a}$ & $613.3^{a}$ & $746.6^{\mathrm{a}}$ \\
\hline & A 1 & $1187.3^{a b}$ & $586.3^{a b}$ & $630.6^{a}$ & $801.4^{a b}$ \\
\hline & A 2 & $1240.9^{b}$ & $601.6^{b}$ & $669.8^{b}$ & $837.4^{b}$ \\
\hline \multirow{3}{*}{ Harvest date $* *$} & I & $1354.9^{b}$ & $539.8^{b}$ & $616.6^{\mathrm{ab}}$ & $837.1^{b}$ \\
\hline & II & $1604.8^{b c}$ & $613.4^{\mathrm{ab}}$ & $647.4^{\mathrm{a}}$ & $955.2^{c}$ \\
\hline & III & $564.9^{a}$ & $564.9^{a b}$ & $649.6^{a}$ & $593.1^{a}$ \\
\hline \multirow{2}{*}{ Fertilization $* * *$} & Standard object & $1127.2^{\mathrm{a}}$ & $481.9^{\mathrm{a}}$ & $553.9^{a}$ & $721.0^{a}$ \\
\hline & $\mathrm{B}+\mathrm{Mo}$ & $1222.5^{b}$ & $663.5^{b}$ & $721.8^{b}$ & $869 .^{b}$ \\
\hline Years & & $1174.9^{c}$ & $572.7^{\mathrm{a}}$ & $637.9^{b}$ & \\
\hline
\end{tabular}

* Control object: Without the use of an attractant; A 1-use of the attractant at the beginning of flowering (BBCH 60); A 2-double use of the attractant: at the beginning and full flowering phase (BBCH 60 and BBCH 65); ** Harvest date I, II, III-harvesting of swaths with an interval of 7 days (I-14 August 2014; 5 August 2015, 10 August 2016; II-22 August 2014, 12 August 2015, 16 August 2016; III-29 August 2014, 19 August 2015, 24 August 2016); ${ }^{* * *}$ Standard fertilization-PK fertilization (35 kg.P and 66.4 kg·K·ha-1); B + Mo-foliar fertilization: $\mathrm{B}-0.35\left(\mathrm{~kg} \cdot \mathrm{ha}^{-1}\right)$ and $\mathrm{Mo}-0.015\left(\mathrm{~kg} \cdot \mathrm{ha}^{-1}\right)$ against the background of uniform PK fertilization $\left(35 \mathrm{~kg} \cdot \mathrm{P}\right.$ and $\left.66.4 \mathrm{~kg} \cdot \mathrm{K} \cdot \mathrm{ha}{ }^{-1}\right)$; letter indices at the means (significant groups) designate the so-called homogeneous groups (statistically homogeneous). The presence of the same letter index with the means (at least one) means that there is no statistically significant difference between them. The following letter indices a, $b$, etc., define groups of means in ascending order.

\subsection{The Mass of 1000 Seeds}

The weight of 1000 seeds varied by the use of attractant, foliar feeding, and harvest time. Only the use of the attractant twice had a significant effect on increasing the weight of 1000 seeds. In 2014, with optimal weather conditions, the use of the attractant was not significant, similarly in 2015, the dry year, no significant influence of the attractant on the value of this feature was found. It was only in 2016, with favorable conditions for the flight of clover by pollinating insects, that a positive effect of attractant applied twice, compared to its introduction once, was observed, in the form of an increase in the weight of 1000 seeds (Table 10).

Fertilization with micronutrients significantly contributed to the increase in MTS, compared to the standard object. In 2014, foliar fertilization with microelements under optimal growth conditions did not result in statistically significant differences in the weight of 1000 seeds. On the other hand, a significant effect of boron and molybdenum fertilization was observed in dry and dry years. At the first harvest date, the best-developed, heaviest seeds were obtained, usually during this period the plants were best supplied with water 
and nutrients. In subsequent harvest dates, the mass of 1000 seeds turned out to be homogeneous in terms of the value of this feature (Table 10).

Table 10. Effect of attractant application, foliar fertilization, harvest time, and years on MTS of red clover (g).

\begin{tabular}{|c|c|c|c|c|c|}
\hline \multirow{2}{*}{\multicolumn{2}{|c|}{ Experiment Factors * }} & \multicolumn{3}{|c|}{ Years } & \multirow{2}{*}{$\bar{x}$} \\
\hline & & 2014 & 2015 & 2016 & \\
\hline \multirow{3}{*}{ Attractant* } & Control object & $1.93^{\mathrm{a}}$ & $1.60^{b}$ & $1.83^{\mathrm{cd}}$ & $1.79^{\mathrm{a}}$ \\
\hline & A 1 & $1.91^{\mathrm{a}}$ & $1.62^{b}$ & $1.79^{\mathrm{c}}$ & $1.77^{\mathrm{a}}$ \\
\hline & A 2 & $1.91^{\mathrm{a}}$ & $1.65^{b}$ & $1.89 \mathrm{ad}$ & $1.82^{b}$ \\
\hline \multirow{3}{*}{ Harvest date ${ }^{* *}$} & I & $1.88^{a b}$ & $1.83^{\mathrm{a}}$ & $1.87^{\mathrm{ab}}$ & $1.86^{b}$ \\
\hline & II & $1.95^{\mathrm{c}}$ & $1.64^{\mathrm{d}}$ & $1.67^{\mathrm{d}}$ & $1.75^{\mathrm{a}}$ \\
\hline & III & $1.93 \mathrm{bc}$ & $1.40^{\mathrm{e}}$ & $1.98^{\mathrm{c}}$ & $1.77^{\mathrm{a}}$ \\
\hline \multirow{2}{*}{ Fertilization $* * *$} & Standard object & $1.92^{\mathrm{a}}$ & $1.57^{\mathrm{b}}$ & $1.79^{\mathrm{d}}$ & $1.76^{\mathrm{a}}$ \\
\hline & $\mathrm{B}+\mathrm{Mo}$ & $1.91^{\mathrm{a}}$ & $1.68^{\mathrm{c}}$ & $1.88^{\mathrm{a}}$ & $1.82^{b}$ \\
\hline Years & & $1.92^{\mathrm{c}}$ & $1.62^{a}$ & $1.84^{b}$ & \\
\hline
\end{tabular}

* Control object: Without the use of an attractant; A 1-use of the attractant at the beginning of flowering (BBCH 60); A 2-double use of the attractant: at the beginning and full flowering phase (BBCH 60 and $\mathrm{BBCH} 65) ;{ }^{* *}$ Harvest date I, II, III-harvesting of swaths with an interval of 7 days (I-14 August 2014; 5 August 2015, 10 August 2016; II-22 August 2014, 12 August 2015, 16 August 2016; III-29 August 2014, 19 August 2015, 24 August 2016); ${ }^{* * *}$ Standard fertilization-PK fertilization (35 kg.P and $\left.66.4 \mathrm{~kg} \cdot \mathrm{K} \cdot \mathrm{ha}{ }^{-1}\right)$; B + Mo-foliar fertilization: $\mathrm{B}-0.35\left(\mathrm{~kg} \cdot \mathrm{ha}^{-1}\right)$ and Mo-0.015 $\left(\mathrm{kg} \cdot \mathrm{ha}^{-1}\right)$ against the background of uniform PK fertilization $\left(35 \mathrm{~kg} \cdot \mathrm{P}\right.$ and $\left.66.4 \mathrm{~kg} \cdot \mathrm{K} \cdot \mathrm{ha}^{-1}\right)$; Letter indices at the means (significant groups) designate the so-called homogeneous groups (statistically homogeneous). The presence of the same letter index with the means (at least one) means that there is no statistically significant difference be-tween them. The following letter indices $a, b$, etc., define groups of means in ascending order.

The thermal and humidity conditions in the years of the research significantly influenced the setting of red conical seeds at particular dates. In the first year of research, the best developed seeds were obtained in the second harvest date, but the difference between the second and third dates turned out to be insignificant. In 2015, a dry year, the heaviest seeds were produced by clover at the earliest harvest date, while the lowest value of this trait was recorded in III time limit. The reason for the decrease in the weight of 1000 seeds was the huge water deficit this season. In 2015, the seeds were characterized by a small size and under-deformed seeds, the so-called 'tailings'. In 2016, a fairly dry year, only the third harvest date turned out to be favorable for the value of this feature, when about $130 \mathrm{~mm}$ of rainfall fell in July, which supplemented significant water shortages. The humidity and thermal conditions significantly influenced the weight of 1000 seeds of red clover. The heaviest seeds were obtained in the optimal, in terms of rainfall, 2014, while the lowest value of this feature was recorded in the driest, 2015. In the years with less favorable weather conditions (2015 and 2016), fertilization effectively increased the weight of 1000 seeds of red clover. Significant differences were noticed in the object with foliar fertilization with microelements (B + Mo), compared to the standard fertilization (Table 10).

The highest weight of 1000 seeds, in 2014 with optimal conditions and a fairly dry year in 2016, was obtained in the objects with foliar fertilization (B + Mo) in cooperation with the application of the attractant twice in III harvest date; while in the dry year of 2015, the best effect of using the attractant and fertilization with microelements was obtained on the first harvest date (Figure 2).

\subsection{Seed Germination Parameters}

\subsubsection{Seed Germination Capacity}

The germination capacity of seeds was related to all the experimental factors (Table 11). 


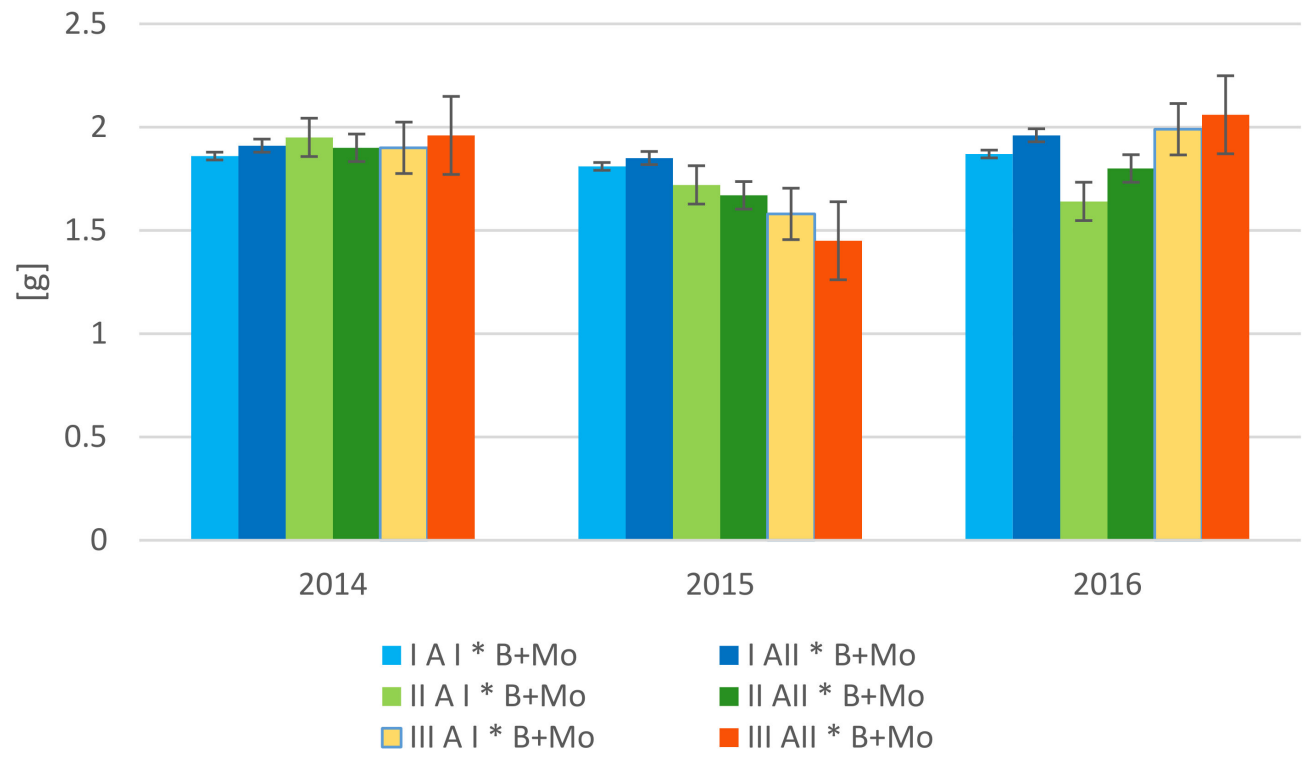

Figure 2. MTS depending on the attractant, fertilization with microelements, and years (g).

Table 11. Effect of attractant application, harvest time, fertilization, and cultivation years on seed germination capacity (\%).

\begin{tabular}{|c|c|c|c|c|c|}
\hline \multirow{2}{*}{\multicolumn{2}{|c|}{ Experiment Factors * }} & \multicolumn{3}{|c|}{ Years } & \multirow{2}{*}{$\bar{x}$} \\
\hline & & 2014 & 2015 & 2016 & \\
\hline \multirow{3}{*}{ Attractant * } & Control object & $91.3^{b}$ & $88.7^{b}$ & $91.1^{\mathrm{ab}}$ & $90.3^{b}$ \\
\hline & A 1 & $93.1^{\mathrm{a}}$ & $90.9^{a b}$ & $92.5^{\mathrm{a}}$ & $92.2^{\mathrm{a}}$ \\
\hline & A 2 & $92.7^{\mathrm{a}}$ & $92.0^{\mathrm{b}}$ & $92.6^{a}$ & $92.4^{\mathrm{a}}$ \\
\hline \multirow{3}{*}{ Harvest dates ** } & I & $91.8^{a}$ & $87.6^{b}$ & $92.1^{a}$ & $90.5^{a}$ \\
\hline & II & $92.3^{a}$ & $92.8^{a}$ & $92.4^{\mathrm{a}}$ & $92.5^{b}$ \\
\hline & III & $93.0^{a}$ & $91.3^{\mathrm{a}}$ & $91.7^{\mathrm{a}}$ & $92.0^{\mathrm{ab}}$ \\
\hline \multirow{2}{*}{ Fertilization $* * *$} & Standard object & $92.2^{a}$ & $88.3^{b}$ & $91.8^{\mathrm{a}}$ & $90.9^{a}$ \\
\hline & $\mathrm{B}+\mathrm{Mo}$ & $92.5^{\mathrm{a}}$ & $92.8^{\mathrm{a}}$ & $92.3^{\mathrm{a}}$ & $92.4^{b}$ \\
\hline Years & & $92.3^{b}$ & $90.5^{a}$ & $92.1^{b}$ & \\
\hline
\end{tabular}

* Control object: Without the use of an attractant; A 1-use of the attractant at the beginning of flowering (BBCH 60); A 2-double use of the attractant: at the beginning and full flowering phase $(\mathrm{BBCH} 60$ and $\mathrm{BBCH} 65) ;{ }^{* *}$ Harvest date I, II, III-harvesting of swaths with an interval of 7 days (I-14 August 2014; 5 August 2015, 10 August 2016; II-22 August 2014, 12 August 2015, 16 August 2016; III-29 August 2014, 19 August 2015, 24 August 2016); ${ }^{* * *}$ Standard fertilization-PK fertilization (35 kg.P and $\left.66.4 \mathrm{~kg} \cdot \mathrm{K} \cdot \mathrm{ha}{ }^{-1}\right)$; B + Mo-foliar fertilization: $\mathrm{B}-0.35\left(\mathrm{~kg} \cdot \mathrm{ha}^{-1}\right)$ and Mo-0.015 $\left(\mathrm{kg} \cdot \mathrm{ha}^{-1}\right)$ against the background of uniform PK fertilization $\left(35 \mathrm{~kg} \cdot \mathrm{P}\right.$ and $\left.66.4 \mathrm{~kg} \cdot \mathrm{K} \cdot \mathrm{ha}^{-1}\right)$; Letter indices at the means (significant groups) designate the so-called homogeneous groups (statistically homogeneous). The presence of the same letter index with the means (at least one) means that there is no statistically significant difference be-tween them. The following letter indices $a, b$, etc., define groups of means in ascending order.

The use of an attractant significantly increased the value of this feature; there was no difference between the multiplicity of applying the 'Pollinus' attractant. Foliar fertilization with micronutrient fertilizers $(\mathrm{B}+\mathrm{Mo})$ significantly increased the seed germination capacity, which is an important achievement due to the problems with germination of seeds of smallseed legumes. However, this effect was strongly related to the meteorological conditions in the years of the study. A significant, proven effect of fertilization of clover with boron and molybdenum was found only in the dry, unfavorable for seed production in 2015 . The seed germination ability was also differentiated by the harvest dates of the 2nd cut, which influenced the value of this feature. The second term (beginning of flowering) turned out to be the most favorable, but the harvest performed a week later turned out to be homogeneous in terms of the value of this feature, compared to the previous one. The conditions in the research years significantly differentiated this effect. Only in dry, 2015, 
a significant dependence of the germination capacity of clover seeds on the date of their harvest was found. The 2nd and 3rd harvest dates of the second cut turned out to be more favorable for the seed germination capacity. Years of randomized research have significantly modified the ability of seeds to germinate. The highest value of this parameter was obtained in 2014, optimal in terms of humidity and thermal conditions, and the lowest, and in dry 2015 (rainfall deficit, high average air temperatures); the germination capacity of seeds was homogeneous in 2014 and 2016. The use of the 'Pollinus' preparation in the cultivation of red clover, both once and twice, in the form of spraying on plants, contributed to an increase in seed germination compared to with the control object; the conditions in the research years significantly differentiated the value of this feature. In 2014, both variants of the use of the 'Pollinus' preparation had a positive effect on the value of this feature, in 2015 only two applications of this preparation brought the expected effect of higher seed germination capacity, and in dry 2016 both terms of using the attractant turned out to be homogeneous in relation to the value of this feature (Table 11).

\subsubsection{Share of Normally Germinating Seeds}

The share of normally germinating seeds was significantly differentiated by factors such as attractant application, fertilization, and their interaction with the years of research. Only a single application of the attractant significantly increased the share of normally germinating seeds, compared to the control. The reaction of red clover to the use of 'Pollinus' was variable in the years of research. In the optimal year for plant growth and development, no significant differences were found in the value of this trait between both variants of the preparation application and the control object. In the dry year of 2015, both dates of using the attractant had a positive effect on the proportion of normally germinating seeds, without differentiating them with the dates of adding the 'Pollinus' preparation. In 2016, a significant effect of the attractant was found only when it was introduced twice, but it was a negative effect of its application (Table 12).

Table 12. Effect of attractant application, harvest time, fertilization, and years on the share of normally germinating seeds (\%).

\begin{tabular}{|c|c|c|c|c|c|}
\hline \multirow{2}{*}{\multicolumn{2}{|c|}{ Experiment Factors * }} & \multicolumn{3}{|c|}{ Years } & \multirow{2}{*}{$\bar{x}$} \\
\hline & & 2014 & 2015 & 2016 & \\
\hline \multirow{3}{*}{ Attractant * } & Control object & $89.5^{c}$ & $68.7^{b}$ & $77.7^{\mathrm{a}}$ & $78.6^{\mathrm{a}}$ \\
\hline & A 1 & $89.8^{c}$ & $72.2^{a b}$ & $78.3^{a}$ & $80.1^{b}$ \\
\hline & A 2 & $90.1^{c}$ & $72.3^{a b}$ & $75.1^{\mathrm{ab}}$ & $79.2^{a b}$ \\
\hline \multirow{3}{*}{ Harvest dates ** } & $\mathrm{I}$ & $88.8^{c}$ & $67.9^{b}$ & $79.1^{\mathrm{a}}$ & $78.6^{\mathrm{a}}$ \\
\hline & II & $90.3^{c}$ & $72.7^{a b}$ & $77.0^{\mathrm{a}}$ & $80.0^{a}$ \\
\hline & III & $90.5^{c}$ & $72.6^{\mathrm{ab}}$ & $75.0^{\mathrm{ab}}$ & $79.3^{a}$ \\
\hline \multirow{2}{*}{ Fertilization ${ }^{* * *}$} & Standard object & $89.6^{b}$ & $68.6^{a}$ & $72.4^{\mathrm{a}}$ & $76.9^{a}$ \\
\hline & $\mathrm{B}+\mathrm{Mo}$ & $90.1^{b}$ & $73.5^{a}$ & $81.6^{c}$ & $81.7^{b}$ \\
\hline Years & & $89.9^{c}$ & $71.1^{\mathrm{a}}$ & $77.0^{b}$ & \\
\hline
\end{tabular}

* Control object: Without the use of an attractant; A 1-use of the attractant at the beginning of flowering (BBCH 60); A 2-double use of the attractant: at the beginning and full flowering phase (BBCH 60 and BBCH 65); ** Harvest date I, II, III-harvesting of swaths with an interval of 7 days (I-14 August 2014; 5 August 2015, 10 August 2016; II-22 August 2014, 12 August 2015, 16 August 2016; III-29 August 2014, 19 August 2015, 24 August 2016); ${ }^{* * *}$ Standard fertilization-PK fertilization (35 kg.P and 66.4 kg.K.ha-1); B + Mo-foliar fertilization: $\mathrm{B}-0.35\left(\mathrm{~kg} \cdot \mathrm{ha}^{-1}\right)$ and $\mathrm{Mo}-0.015\left(\mathrm{~kg} \cdot \mathrm{ha}^{-1}\right)$ against the background of uniform PK fertilization $\left(35 \mathrm{~kg} \cdot \mathrm{P}\right.$ and $\left.66.4 \mathrm{~kg} \cdot \mathrm{K} \cdot \mathrm{ha}{ }^{-1}\right)$; Letter indices at the means (significant groups) designate the so-called homogeneous groups (statistically homogeneous). The presence of the same letter index with the means (at least one) means that there is no statistically significant difference be-tween them. The following letter indices a, $b$, etc., define groups of means in ascending order.

The foliar feeding of red clover with boron and molybdenum significantly increased the share of normally germinating seeds, on average by $6.2 \%$, compared to the standard object. However, the clover responded differently to fertilization during the research years. Only in 2016, the dry year, a significant effect of fertilizing plants with microelements 
$(\mathrm{B}+\mathrm{Mo})$ was found, while in the remaining years these combinations turned out to be homogeneous with the standard object with phosphorus-potassium fertilization. Seed collection dates did not have a decisive influence on the share of normally germinating seeds. However, in particular years of research, a different reaction of seeds to this factor was observed. In 2014, no significant differences were found between the harvest dates, but such differences occurred in dry 2015 and dry 2016. In 2015, the best germinating seeds were obtained from the second term, although the share of normally germinating seeds was homogeneous, as in the third term, and the highest number of normally germinating seeds, in 2016, was obtained from the first harvest date for seeds. The largest share of normally germinating seeds in the general sample was found in the optimal, in terms of humidity and thermal conditions, 2014, and the lowest in the dry year 2015 (Table 12).

\subsubsection{Share of Seeds Germinating Abnormally}

This fraction has a negative effect on the sowing value of red clover seeds. Seeds germinating improperly, with an inadequately developed root system, were determined on day 10 from the start of the experiment. The share of seeds germinating abnormally was small, of the order of $1.8-7.0 \%$. The use of attractant and foliar fertilization (B + Mo) did not limit the share of abnormally germinating seeds. However, the weather conditions combined with the use of the attractant had a varied effect on the proportion of abnormally germinating seeds. In 2014, a decrease in the participation of this type of seeds was observed in both objects with the use of an attractant. In 2015 and 2016, such a reaction was recorded only in the facility with two applications of 'Pollinus', compared to the control facility (Table 13).

Table 13. Effect of attractant application, harvest date, fertilization, and years on the share of seeds germinating abnormally (\%).

\begin{tabular}{|c|c|c|c|c|c|}
\hline \multirow{2}{*}{\multicolumn{2}{|c|}{ Experiment Factors * }} & \multicolumn{3}{|c|}{ Years } & \multirow{2}{*}{$\bar{x}$} \\
\hline & & 2014 & 2015 & 2016 & \\
\hline \multirow{3}{*}{ Attractant* } & Control object & $4.6^{\mathrm{a}}$ & $2.3^{\mathrm{cd}}$ & $6.2^{b}$ & $4.4^{\mathrm{a}}$ \\
\hline & A 1 & $4.0^{\mathrm{ad}}$ & $2.1^{\mathrm{cd}}$ & $6.1^{\mathrm{ba}}$ & $4.1^{\mathrm{a}}$ \\
\hline & A 2 & $4.0^{\mathrm{ad}}$ & $1.8^{c}$ & $5.8^{a}$ & $3.9^{\mathrm{a}}$ \\
\hline \multirow{3}{*}{ Harvest date ${ }^{* *}$} & I & $4.5^{\mathrm{a}}$ & $2.4^{\mathrm{c}}$ & $4.9^{\mathrm{ad}}$ & $4.0^{\mathrm{a}}$ \\
\hline & II & $4.0^{\mathrm{ac}}$ & $1.8^{\mathrm{b}}$ & $6.2^{\mathrm{de}}$ & $4.0^{\mathrm{a}}$ \\
\hline & III & $4.1^{\mathrm{ac}}$ & $2.0 \mathrm{bc}$ & $7.0^{\mathrm{e}}$ & $4.4^{\mathrm{a}}$ \\
\hline \multirow{2}{*}{ Fertilization $* * *$} & Standard object & $4.2^{\mathrm{b}}$ & $2.3^{\mathrm{a}}$ & $6.0^{c}$ & $4.2^{\mathrm{a}}$ \\
\hline & $\mathrm{B}+\mathrm{Mo}$ & $4.3^{b}$ & $1.8^{\mathrm{a}}$ & $6.1^{c}$ & $4.0^{\mathrm{a}}$ \\
\hline Years & & $4.2^{b}$ & $2.1^{\mathrm{a}}$ & $6.0^{c}$ & \\
\hline
\end{tabular}

* Control object: Without the use of an attractant; A 1-use of the attractant at the beginning of flowering (BBCH 60); A 2-double use of the attractant: at the beginning and full flowering phase (BBCH 60 and BBCH 65); ** Harvest date I, II, III-harvesting of swaths with an interval of 7 days (I-14 August 2014; 5 August 2015, 10 August 2016; II-22 August 2014, 12 August 2015, 16 August 2016; III-29 August 2014, 19 August 2015, 24 August 2016); ${ }^{* * *}$ Standard fertilization-PK fertilization (35 kg.P and $\left.66.4 \mathrm{~kg} \cdot \mathrm{K} \cdot \mathrm{ha}{ }^{-1}\right)$; B + Mo-foliar fertilization: $\mathrm{B}-0.35\left(\mathrm{~kg} \cdot \mathrm{ha}^{-1}\right)$ and Mo-0.015 $\left(\mathrm{kg} \cdot \mathrm{ha}^{-1}\right)$ against the background of uniform PK fertilization ( $35 \mathrm{~kg} \cdot \mathrm{P}$ and $\left.66.4 \mathrm{~kg} \cdot \mathrm{K} \cdot \mathrm{ha}{ }^{-1}\right)$; Letter indices at the means (significant groups) designate the so-called homogeneous groups (statistically homogeneous). The presence of the same letter index with the means (at least one) means that there is no statistically significant difference be-tween them. The following letter indices $a, b$, etc., define groups of means in ascending order.

The dates of harvesting seeds from the second cut did not significantly affect the number of seeds germinating abnormally. However, a varied response to this factor was observed over the years of the study. In 2014 and 2015, the most seeds of this type were found in the first harvest date of the second cut, and in 2016 in the last cut, which was associated with high rainfall at that time. The share of abnormally germinating seeds in the studied sample was determined to the greatest extent by the meteorological conditions in the years of the study. The lowest number of defective seeds in the seed material was found in dry 2015, and the highest number in dry 2016 with a very wet July (Table 13). 


\subsubsection{Number of Hard Seeds}

Hard seeds are classified as inferior, bad seed material, moreover, they cause higher costs of seed processing. The quality of the seed material is related to the hardness and low germination of seeds. This feature may be anatomical or physiological, but hard seeds are most numerous in the group of legumes. The use of an attractant, in both terms, had no significant effect on the presence of hard seeds. Among the examined factors, only the fertilization with microelements (B + Mo) significantly decreased their share (Table 14). Significant interaction between fertilization $\times$ years was found. Only in 2014, no reaction of seeds to fertilization was observed. In 2015 and 2016, a decrease in the number of hard seeds was noticed after the application of plant feeding with microelements $(\mathrm{B}+\mathrm{Mo})$; in 2016, there was an almost 2-fold decrease in hard seeds, compared to standard fertilization. The dates of harvesting clover for seeds did not affect the value of this parameter of seed quality. There was also no correlation between seed harvesting dates and the research years. The weather conditions in the years of the research had the greatest impact on this feature. The largest share of hard seeds was observed in the dry year of 2015, and the smallest one was in the optimum, in terms of hydrothermal, 2014 (Table 14).

Table 14. Effect of attractant application, harvesting, and fertilization dates and years on the number of hard seeds (pcs.).

\begin{tabular}{|c|c|c|c|c|c|}
\hline \multirow{2}{*}{\multicolumn{2}{|c|}{ Experiment Factors * }} & \multicolumn{3}{|c|}{ Years } & \multirow{2}{*}{$\bar{x}$} \\
\hline & & 2014 & 2015 & 2016 & \\
\hline \multirow{3}{*}{ Attractant * } & Control object & $2.2^{\mathrm{a}}$ & $28.5^{c}$ & $13.4^{\mathrm{b}}$ & $14.7^{\mathrm{a}}$ \\
\hline & A 1 & $3.2^{\mathrm{a}}$ & $24.5^{c}$ & $14.3^{b}$ & $14.0^{\mathrm{a}}$ \\
\hline & A 2 & $2.5^{a}$ & $25.7^{c}$ & $17.5^{b}$ & $15.2^{\mathrm{a}}$ \\
\hline \multirow{3}{*}{ Harvest date ${ }^{* *}$} & I & $3.0^{\mathrm{a}}$ & $28.4^{\mathrm{c}}$ & $13.0^{b}$ & $14.8^{\mathrm{a}}$ \\
\hline & II & $2.3^{a}$ & $25.0^{\mathrm{c}}$ & $15.4^{\mathrm{b}}$ & $14.2^{\mathrm{a}}$ \\
\hline & III & $2.5^{\mathrm{a}}$ & $25.3^{c}$ & $16.8^{\mathrm{b}}$ & $14.8^{\mathrm{a}}$ \\
\hline \multirow{2}{*}{ Fertilization $* * *$} & Standard object & $2.7^{\mathrm{a}}$ & $28.1^{\mathrm{c}}$ & $20.0^{\mathrm{b}}$ & $16.9^{b}$ \\
\hline & $\mathrm{B}+\mathrm{Mo}$ & $2.6^{\mathrm{a}}$ & $24.3^{b c}$ & $10.5^{\mathrm{d}}$ & $12.3^{\mathrm{a}}$ \\
\hline Years & & $2.6^{a}$ & $26.2^{b}$ & $15.0^{c}$ & \\
\hline
\end{tabular}

* Control object: Without the use of an attractant; A 1-use of the attractant at the beginning of flowering (BBCH 60); A 2-double use of the attractant: at the beginning and full flowering phase $(\mathrm{BBCH} 60$ and $\mathrm{BBCH} 65) ;{ }^{* *}$ Harvest date I, II, III-harvesting of swaths with an interval of 7 days (I-14 August 2014; 5 August 2015, 10 August 2016; II-22 August 2014, 12 August 2015, 16 August 2016; III-29 August 2014, 19 August 2015, 24 August 2016); ${ }^{* * *}$ Standard fertilization-PK fertilization (35 kg.P and $66.4 \mathrm{~kg} \cdot \mathrm{K} \cdot \mathrm{ha}{ }^{-1}$ ); B + Mo-foliar fertilization: $\mathrm{B}-0.35\left(\mathrm{~kg} \cdot \mathrm{ha}^{-1}\right)$ and Mo- $0.015\left(\mathrm{~kg} \cdot \mathrm{ha}^{-1}\right)$ against the background of uniform PK fertilization $\left(35 \mathrm{~kg} \cdot \mathrm{P}\right.$ and $\left.66.4 \mathrm{~kg} \cdot \mathrm{K} \cdot \mathrm{ha}{ }^{-1}\right)$; Letter indices at the means (significant groups) designate the so-called homogeneous groups (statistically homogeneous). The presence of the same letter index with the means (at least one) means that there is no statistically significant difference be-tween them. The following letter indices $a, b$, etc., define groups of means in ascending order.

\subsection{Number of Seeds Infected with Fungal Pathogens}

The presence of seeds infected with fungal diseases in the seed material was in the range of $0.4-3.7 \%$. The number of seeds infected with fungal pathogens was shaped by all the experimental factors. Bringing the attractant to the plants during their vegetation contributed to a significant reduction of infected seeds in the tested samples by $17.4 \%$ in objects with single spraying to $26.1 \%$ in combinations with the use of the attractant 'Pollinus' twice (Table 15).

The influence of the attractant on the health of seeds depended, however, on the meteorological conditions in the years of the research. In the optimum, in terms of hydrothermal 2014 and quite dry 2016, the least seeds infected with fungal diseases were in the objects with a single use of the attractant. In the dry year of 2015, the greatest reduction in seeds infected with fungal pathogens was achieved by applying the 'Pollinus' preparation twice. The number of seeds infected with fungal pathogens was significantly differentiated by the dates of harvesting clover for seeds. Additionally, the harvest date was the least fa- 
vorable in all the years of experience. The longer maturation of the seeds favored normal germination and reduced the infestation of the seeds with fungal pathogens. The use of foliar fertilization with microelements $(B+M o)$ did not significantly reduce the share of seeds infected with fungal pathogens, only in the dry, 2015 year, such a relationship was observed (Table 15).

Table 15. Effect of attractant application, harvest time, fertilization date, and years on the number of seeds infected with fungal pathogens (pcs.).

\begin{tabular}{|c|c|c|c|c|c|}
\hline \multirow{2}{*}{\multicolumn{2}{|c|}{ Experiment Factors * }} & \multicolumn{3}{|c|}{ Years } & \multirow{2}{*}{$\bar{x}$} \\
\hline & & 2014 & 2015 & 2016 & \\
\hline \multirow{3}{*}{ Attractant * } & Control object & $3.7^{\mathrm{c}}$ & $0.5^{\mathrm{a}}$ & $2.7^{b c}$ & $2.3^{\mathrm{a}}$ \\
\hline & A 1 & $2.9^{b c}$ & $1.3^{\mathrm{ab}}$ & $1.4^{\mathrm{ab}}$ & $1.9^{b}$ \\
\hline & A 2 & $3.4^{c}$ & $0.2^{\mathrm{a}}$ & $1.6^{\mathrm{ab}}$ & $1.7^{\mathrm{b}}$ \\
\hline \multirow{3}{*}{ Harvest date ** } & $\mathrm{I}$ & $3.7^{c}$ & $1.3^{\mathrm{ab}}$ & $3.0^{b c}$ & $2.6^{b}$ \\
\hline & II & $3.4^{\mathrm{c}}$ & $1.5^{b}$ & $1.5^{\mathrm{ab}}$ & $1.8^{\mathrm{a}}$ \\
\hline & III & $2.8^{b c}$ & $0.2^{\mathrm{a}}$ & $1.3^{c}$ & $1.5^{\mathrm{a}}$ \\
\hline \multirow{2}{*}{ Fertilization $* * *$} & Standard object & $3.5^{\mathrm{d}}$ & $0.9^{\mathrm{a}}$ & $1.7^{\mathrm{c}}$ & $2.0^{\mathrm{a}}$ \\
\hline & $\mathrm{B}+\mathrm{Mo}$ & $3.1^{\mathrm{cd}}$ & $0.4^{\mathrm{b}}$ & $2.2^{\mathrm{ac}}$ & $1.9^{\mathrm{a}}$ \\
\hline Years & & $3.3^{c}$ & $0.6^{\mathrm{a}}$ & $1.9^{b}$ & \\
\hline
\end{tabular}

* Control object: Without the use of an attractant; A 1-use of the attractant at the beginning of flowering (BBCH 60); A 2-double use of the attractant: at the beginning and full flowering phase (BBCH 60 and BBCH 65); ** Harvest date I, II, III-harvesting of swaths with an interval of 7 days (I-14 August 2014; 5 August 2015, 10 August 2016; II-22 August 2014, 12 August 2015, 16 August 2016; III-29 August 2014, 19 August 2015, 24 August 2016); ${ }^{* * *}$ Standard fertilization-PK fertilization (35 kg.P and $66.4 \mathrm{~kg} \cdot \mathrm{K} \cdot \mathrm{ha}{ }^{-1}$ ); B + Mo-foliar fertilization: $\mathrm{B}-0.35\left(\mathrm{~kg} \cdot \mathrm{ha}^{-1}\right)$ and Mo- $0.015\left(\mathrm{~kg} \cdot \mathrm{ha}^{-1}\right)$ against the background of uniform PK fertilization $\left(35 \mathrm{~kg} \cdot \mathrm{P}\right.$ and $\left.66.4 \mathrm{~kg} \cdot \mathrm{K} \cdot \mathrm{ha}{ }^{-1}\right)$; Letter indices at the means (significant groups) designate the so-called homogeneous groups (statistically homogeneous). The presence of the same letter index with the means (at least one) means that there is no statistically significant difference be-tween them. The following letter indices $a, b$, etc., define groups of means in ascending order.

\section{Discussion}

\subsection{Effect of Attractants}

The study analyzed the influence of various meteorological and agrotechnical conditions on the yield and quality characteristics of red clover seeds. In order to eliminate unfavorable weather conditions, appropriate agrotechnics can be used, including fertilization with microelements, as well as preparations stimulating flowering and increasing the attractiveness of plants for pollinating insects. Among them, insects from the bee superfamily play the most important role in pollination, which include several hundred species of solitary bees, about 30 species of bumblebees, and the honeybee (Aphis mellifera) [13,15,45-48]. Knowing the species composition and abundance of bees is of increasing importance not only for fruit growers but also for farmers, especially in the case of seed crops. Honeybees are considered to be the most effective and ideal pollinators in improving the performance of cross-pollinated crops. The success of pollination with honeybees depends on their performance on the target crop compared with other competing plants nearby [15]. Proper assessment of the number and species composition of bees makes it possible to determine their role in plantations requiring pollination and effective intervention in cases of insufficient pollinator number [45]. Although no factor specific for the production of red clover was identified in this study, which would make a difference, the studies by Banaszak [46] and Semkiw [49] showed a rich native fauna of bees, bumblebees, and hoverflies in the experiment site (Felin) during the flowering of red clover. According to the data of the Veterinary Inspection, there are about 1.68 million bee colonies in Poland, and the most of these colonies are in the Lublin region $(11.7 \%$ of the total), and the infestation is 7.8 colonies $\mathrm{km}^{2}$; with an average for Poland of 5.4 families. $\mathrm{km}^{2}$. Given the projected increase in red clover production in the country, as well as in the EU's protein programs, there is a need to preserve existing populations and adopt an entomofauna management 
strategy that will encourage the accumulation of native bee fauna in red clover fields and in the surrounding landscapes. Hence, building knowledge about the causes of pollinator fluctuations and the impact of the decline in pollinator numbers on other species and ecosystems is essential [12,50-53].

The preparation 'Pollinus', used in the conducted studies, whose active ingredients imitate the pheromone secreted by scout bees to indicate the source of fertility to collectors, increased the attractiveness of flowers that would normally be considered unattractive because of too long a flower tube, hindering access to nectar, or a small amount of nectar secreted. As a result, bees find the plantation sprayed with attractant and do not look for nectar on competing flowers. Flowering stimulation of red clover, i.e., the use of attractants, significantly influenced the yield of seeds of this species. There are few references to such works in the available literature. The use of attractant in our research, in the phase of the beginning and full flowering of clover (60 and 65 in the $99^{\circ} \mathrm{BBCH}$ scale), this led to the assumption that there was a positive effect on the activity of pollinators, the flight of bees and bumblebees. Nithya et al. [53] using the Fruit Boost preparation, in Indian conditions, increased the yield of sesame by $48.4-58.9 \%$, compared to the control. In the opinion of Janas et al. [9] by stimulating flowering with a preparation attracting pollinators, the yield of red clover can be even twice as high as compared to the control object. In the conducted studies, the seed yield was higher by $7.3-12.2 \%$, depending on the number of times the treatment was performed, compared to the control object. The application of the attractant twice, in the 60 and $65 \mathrm{BBCH}$ stages, gave the highest seed yield. In addition, a beneficial effect of the 'Pollinus' preparation was observed not only on the yield of red clover seeds, but also on some elements of their quality. Nithya et al. [53] characterize attractants as natural or partially natural substances, with aroma qualities attracting bees to plants with unattractive flowers or when competing flowering plants grow around the plantation awaiting pollination. The use of the preparation increases the pollen collection activity by bees and also contributes to better pollination of plants. It also makes flowers more attractive and improves the work efficiency of bees and other insects, which also pollinate plants, resulting in larger and better-quality crops. The greatest effect of attractant application was noted mainly in the variants with two applications of the preparation during flowering of the red clover. This may be due to the better flowering conditions of the red clover during the second application, when the plants are fully flowering. Mrówczyński [16], Semkiw [49], and Malerbo-Souza et al. [15] claim that the attractant 'Pollinus' is completely safe for humans and animals, also for all predatory and parasitic insects. It also does not cause any negative effects on plants. The conducted research shows that it is possible to perform at least two treatments with this preparation on the seed clover plantation. The first is at the beginning of flowering, when about 10-15\% of flowers are open, the second in full flowering, when about $90 \%$ of flowers are fully open. The use of the 'Pollinus' preparation, according to Malerbo-Souza et al. [15], definitely increases the profitability of production.

The 'Pollinus' preparation contributed to the increase in the proportion of normally germinating seeds, although it was not the only impact on the value of these features. It was also shaped by other factors of the experiment (fertilization, seed harvest dates), as well as uncontrolled factors, such as the course of the weather and soil conditions.

\subsection{Effect of Fertilization with Microelements}

Feeding plants with microelements significantly affects the seed yield, especially in the conditions of the existing deficiency of this element in the soil. The nutritional needs of plants in relation to boron are different, which results mainly from genetic conditions. Red clover belongs to the group of plants whose nutritional requirements are high and fall within the wide range of $100-500 \mathrm{~kg} \cdot \mathrm{ha}^{-1} \mathrm{NPK}[34,45]$. Therefore, there is a need for research in this direction, because the research on the abundance of boron in the soil, carried out before the experiment was established, showed that the abundance of this element is medium or low. This means that the nutritional needs of red clover are not sufficiently 
covered [38]. Mentions about the effect of fertilizing plants with microelements on growth, their content in various organs, including seeds, are included in the works of Wilczek and Ćwintal [54] in studies on Trifolium pratense, Kotecki and Janeczek [55] in studies on molybdenum, molybdenum, and boron collectively and more recently Kaiser et al. [56]. In the conducted research, the application of the combined Mo + B fertilization significantly increased the yield of red clover seeds by $20.6 \%$, compared to the standard object. There was also a positive effect of fertilization with these microelements on other seed quality characteristics (germination capacity, number of normally germinating seeds) in relation to the standard object. The values of undesirable features, such as the number of hard seeds, seeds germinating abnormally, and infected with fungal diseases, decreased. Tomić et al. [45] conducted experiments with foliar fertilization of red clover with boron during the second regrowth in the second year. Although the seed yield showed a significant increase in the boron-treated plants in the optimal year compared to the control $(26.0 \%)$, its increase was significantly higher in the year with abundant rainfall during the flowering period $(43.2 \%)$. Sufficient boron supply for red clover plants in seed production had a significant, positive effect even under conditions that made pollination difficult. According to Starck [57,58], a good supply of molybdenum to plants has a beneficial effect on the photosynthesis process, including the formation of chlorophyll, which causes, among others, increasing plant resistance to fungal and bacterial pathogens and water deficiency.

Molybdenum, together with boron, is responsible for the proper course of pollen formation and pollination of flowers. This element participates primarily in the nitrogen metabolism of plants and plays an essential role in the process of fixing atmospheric nitrogen. Molybdenum is used by selected enzymes to carry out redox reactions. Enzymes that require molybdenum to function include nitrate reductase, xanthine dehydrogenase, aldehyde oxidase, and sulfite oxidase. Loss of Mo-dependent enzymatic activity (due to low intrinsic molybdenum levels) influences plant development, in particular processes related to nitrogen metabolism and the synthesis of phytohormones, abscisic acid, and indole-3-butyric acid. There is currently little information on how plants get molybdate from soil solution and redistribute it in the plant. Molybdenum deficiencies are considered rare in most areas of agricultural crops; however, the phenotype is often misdiagnosed and attributed to other effects related to its role in various enzymatic redox reactions. Molybdenum foliar fertilization can effectively replenish internal molybdenum deficiencies and save the activity of molybdenzymes. Therefore, a careful analysis of the existing transport mechanisms of prokaryotic molybdate, as well as a re-examination of known anion transport mechanisms present in plants, will help determine how this important trace element accumulates $[5,55,57]$. Hence, molybdenum fertilization increases the amount of nitrogen in the plant, improves the quality parameters of the crop, increases the protein nitrogen content, and affects the amino acid composition of proteins, while reducing the nitrate content in plants. This is of particular importance in the case of legumes, supporting the formation of root nodules, thanks to which the plants can use atmospheric nitrogen. Molybdenum is also involved in the transformation of phosphorus, facilitates the absorption of iron by plants, and increases the content of carotene, vitamin $C$, vitamin $\mathrm{P}$, and riboflavin in plants. In addition, molybdenum increases plant resistance to cold and increases their resistance to drought. Plants properly nourished with this element in periods of water deficiency grow better, giving higher yields, which is associated with the growth of the root system, which enables the plant to take up water from the deeper layers of the soil [5,56]. Insufficient use of molybdenum in red clover seed plantations may be caused by various biotic and abiotic factors. The main factor that reduces the availability of molybdenum from soil is its $\mathrm{pH}$. On acidic soils, its solubility and bioavailability are low, because it precipitates in the form of hardly available iron and aluminum molybdate. From neutral and alkaline soils, it is more easily absorbed and can be absorbed in sufficient quantity for the nutritional needs of plants [56]. In the opinion of many authors, an adequate supply of micronutrients to crops may improve the vigor of their seeds. Wilczek and Ćwintal [34] found positive yield-generating effects of foliar fertilization, both with 
boron and molybdenum. Wilczek and Ćwintal [54] proved that fertilization of clover with boron at a dose of $0.3 \mathrm{~kg}^{-1}$ and molybdenum at doses of 0.01 and $0.015 \mathrm{~kg} \cdot \mathrm{ha}{ }^{-1}$, significantly increased the energy and germination capacity of red clover seeds and the participation of normally germinating seeds, and decreased the share of seeds germinating abnormally. Molybdenum applied as foliar application, regardless of the dose, decreased the share of seeds infected with fungal diseases, and boron had no effect on this feature, while the combined use of boron and molybdenum increased their share. Grzyś [59] believes, however, that fertilization of red clover with microelements causes changes in the chemical composition of seeds, which may, in turn, affect the sowing value of seeds in the next year.

\subsection{Seed Harvest Dates}

The flowering time of clover in Poland is about 5 weeks, while in the second cut, the plants bloom slightly shorter than in the first cut, especially in dry and warm weather $[35,60,61]$.

In the opinion of Wilczek and Ćwintal [34,54], Gaweł [1], Żuk-Gołaszewska [62], the differences in the time of flowering of the first cut of red clover and in the time of flowering of the second cut are small between individual places, as they reach the order of a few days. The flowering season usually begins in the first 10 days of June and ends in the second 10 days of August. The difference in the beginning of the flowering season between the years was about one week, and even less days at the time of menopause. The flowering abundance of red clover was subject to large fluctuations depending on the year. The most important factor in this period was the growth condition, which depended mainly on the system of meteorological conditions in winter and early spring, and on soil moisture and temperature during the growing season, and to a lesser extent on the type of soil. Under favorable conditions, clover can produce up to 1600 heads per $1 \mathrm{~m}^{2}$, which is more than three times more than is considered sufficient to produce a good seed yield (500-800 kg.ha $\left.{ }^{-1}\right)$. However, in the case of poor growth, flowering may be too sparse, not allowing for obtaining a high yield of seeds even in the most favorable conditions $[45,47,50,63,64]$.

The length of the red clover flower tube depends on the meteorological conditions; cool and wet weather favors the development of a longer flower tube ( $>9 \mathrm{~mm})$, and dry and warm weather a shorter flower tube $(<8 \mathrm{~mm})[46,48]$. Geographical variation causes the length of the flower tube to change as it travels from north to south, and is more pronounced in the dry years, in the second cut of the clover, which can result in a difference in tube length between the north and south regions of up to $2 \mathrm{~mm}$. The red clover from the second cut may produce a flower tube that is shorter than the clover from the first cut, but only in favorable, dry and warm weather, while with more rainfall, the opposite phenomenon may even occur. The nectar in clover flowers generally rises to a height of $1.0-1.5 \mathrm{~mm}$, but may be as high as $2 \mathrm{~mm}$ in some cases and as low as $0.5 \mathrm{~mm}$ in others. It depends not so much on the year and the swath as on the locality. According to Wilczek and Ćwintal [5] is a certain relationship between the weaker nectarizing of clover and more abundant potassium fertilization. Moreover, warm and dry summers generally favor better nectarizing of clover than cool and wet summers [54]. Jabłoński and Kotłowski [65] suggest that the honey yield of red clover, with medium flowering (about 600 heads per $1 \mathrm{~m}^{-2}$ ) and medium nectarizing, can reach up to $100 \mathrm{~kg} \cdot \mathrm{ha}^{-1}$, and with rich flowering and abundant nectar even over $200 \mathrm{k} \cdot \mathrm{ha}^{-1}$. With the length of the flower tube about $8 \mathrm{~mm}$ and the height of the nectar pillar about $1.5 \mathrm{~mm}$, the honeybee, according to Jabłoński and Kotłowski [65], Denisow [63], should not have any major difficulties in collecting nectar from the clover flower. However, in the case of very high numbers of bumblebees on clover, honeybees may not benefit from the benefit, despite the phenomenon of shortening the flower tube, because bumblebees will be stronger competitors. Such circumstances in the Polish climatic conditions can be expected rather in small plots, and not in production conditions, where there are always too few wild bee insects. The flight of the clover by the bees may be, regardless of the length of the flower tube, very weak (several dozen bees per $1 \mathrm{ha}$ ) 
or very good (several thousand bees per $1 \mathrm{ha}$ ), because these insects are interested not only in nectar but also in red clover pollen. In the opinion of Wilczek and Ćwintal [5], Przybylska et al. [64], Jabłoński and Kotłowski [65] the number of honeybees on clover depends primarily on the presence of other attractive nectar-producing and pollen-bearing plants in the vicinity during the flowering period of the clover. Thus, apart from numerous agricultural arguments, the entomological and beekeeping argument also supports leaving a second cut of clover for seeds, when most of the honey plants usually end their flowering.

\subsection{Influence of Meteorological Conditions on the Seed Yield and Its Structure Elements}

Soil water resources as well as thermal and rainfall conditions have a significant impact on the yielding of red clover plants. A particularly important phenomenon is the amount of water stored in the soil and its availability and the possibility of using it by plants throughout the growing season. Wilczek and Ćwintal [35] believe that the yield of red conic seeds depends to a greater extent on weather conditions than on agrotechnical factors. The conducted research partially confirms this statement. This is evidenced by the yields obtained in individual years of research with different temperature and rainfall levels. The weather, apart from the main influence on plant vegetation, also effectively regulates the intensity of flight of pollinating insects. Wet weather, with high rainfall and high relative air humidity during the flowering of clover, makes it difficult or impossible to pollinate red clover flowers. Due to hot and sunny days, pollinators stop their flights completely at noon [35,52,54]. In the years 2014-2016, the weather varied greatly. From a fairly wet year, through a hot year with low average rainfall, to a year with high average air temperature with a rainy end of summer, which determined the significant variability of the seed yield and their sowing quality.

Żuk-Gołaszewska et al. [4] showed differences between the mechanical properties of seeds depending on the variety, sowing density, and years of research. All mechanical parameters of seeds depended on the climatic conditions in the years of research; the cultivation of clover in the years with excess rainfall increased the value of these parameters. These authors also suggest that the inhibition of physical rest in Trifolium pratense seeds is characterized by a significant decrease in the value of $\theta \mathrm{H}$, while the remaining model parameters were relatively constant. The use of the 'hydrotime' model to describe and predict disruption of physical dormancy could be an effective approach, especially for crop species such as red clover that do not contain too many hard seeds.

The number and weight of seeds produced by red clover per unit area depends, inter alia, on the abundance of flowering and on the sufficient number of pollinating insects and the degree of seed setting from pollinated flowers. The second and third factors depend to the greatest extent on the meteorological conditions during the flowering period, which is confirmed by the results obtained in the conducted research. In Sweden, it has been shown that the yield of red clover seeds has decreased since the 1960s, and the variability of the seed yield has doubled in recent decades [24]. Our approach cannot confirm a causal link between changes in relative abundance of bumblebees and lower and more variable yields, but we provide strong evidence to support this explanation.

The conducted research showed a greater impact of humid conditions on the yield of clover seeds and its quality elements than on thermal conditions. A good yield of clover seeds was favored by the temperature, oscillating in Felin between 14.6 and $15.0{ }^{\circ} \mathrm{C}$. A clear upward trend in the yield of red clover seeds could be observed when the total rainfall during the growing season increased to a value above $330-350 \mathrm{~mm}$. Soil water resources as well as thermal and rainfall conditions have a significant impact on the yield of red clover. An important phenomenon is not the mere presence of water in the soil, but its quantity, availability, and the possibility of using it by red clover plants during the growing season. According to Kołodziej [61] in the Lublin region, the average annual rainfall amounts from $400 \mathrm{~mm}$ in the north to $500 \mathrm{~mm}$ in the south. Thus, the sum of atmospheric precipitation in Felin was much below this value. The water needs of red clover, even with the use of correct agricultural technology, depend mainly on the cultivation area, length of vegetation, 
variety, type, and type of soil [35,54]. In the opinion of Wilczek and Ćwintal [54], significant threats to the yield of clover seeds are excessive moisture levels, both in the sowing period, and insufficient moisture levels in the second half of the growing season, before harvesting. According to Wilczek and Ćwintal [34], in south-eastern Poland, the yield of clover is negatively correlated with the values of the atmospheric humidity index in April and the amount of rainfall in July. According to Wilczek [45], the water needs of red clover reach $350 \mathrm{~mm}$ during the growing season, and according to Putts et al. [50] - in the conditions of Western and Northern Europe-500-600 mm, so almost twice as large. The Kalbarczyk [60], when assessing the temporal and spatial distribution of rainfall, showed that the average area of the country with optimal rainfall during the vegetation of clover for seeds was $25 \%$, almost three times more than the area with optimal rainfall for clover. Adapting and introducing varieties of seed red clover to conditions less favorable to cultivation may require in the future an increase in the amount of water retained in the soil by introducing infrastructure for small water retention and renaturalization of wetland habitats. Therefore, the correct location of the red clover grown for seed, especially cultivars with weaker root systems, will be of key importance in this case.

\subsection{Possibilities of Improving Seed Production of Red Clover}

The question of whether perennial plants age at the organism level remains unresolved. One of the objectives of the research was also to determine whether the age of the plants may affect the production and quality of seeds. This problem is constantly considered by physiologists, biologists, bioengineers, and farmers [54,56-58]. Increased plant size may explain the loss of seed viability, but older and smaller individuals in natural populations can avoid aging in terms of loss of seed viability and vitamin E levels, compared to younger individuals. Annuals have been proven to enter a controlled aging program. In most cases, it is associated with the flowering of monocarpic plants (annuals, biennials, and some perennials with one reproductive episode). It is, however, a matter of the current debate as to whether the aging of perennials is due to the same reason. Recent studies have shown signs of aging at the whole plant level in perennials [58], other authors have reported no signs of aging as the plants age [6]. These results pose a new challenge to the theory of biological aging as they question whether aging in living organisms is universal. The counter arguments are that perennials retain their ability to unfold new leaves and grow throughout their lives. According to Martínková et al. [66] aging is a process of loss of fitness and is shaped by a trade-off between maintenance and reproduction, which makes reproduction increasingly uncertain and maintenance more expensive with age. In perennial plants, restrictions on growth and fertility are signs of aging. However, the disturbances provide an opportunity to reset the aging clock, thus potentially aging mitigation. While the disturbance is capable of resetting the plant's aging clock, it is so detrimental to plant health that recovery only serves, at best, to mitigate slight signs of aging. Thus, in terms of lifelong seed production, damaged/wounded seeds have not been more successful than seeds without damage.

Recently, efforts have been made to increase the area of red clover cultivation in the sowing structure, due to the EU and national agricultural programs. Therefore, the demand for seeds is increasing, the productivity of which per ha is still insufficient. The cause of this condition is, among others, insufficient pollination of flowers $[7,8,15,53]$. The production of red clover seeds requires a special location of the plantation in areas compatible with soil and climate requirements and rich in pollinating insects. In the area of the research, there is a sufficient number of pollinating insects capable of pollinating the red clover. In the conditions of south-eastern Poland, such research is of particular importance in regions where the economy is shifting from small-scale to large-scale. The constantly growing areas of monocultures can lead to a decrease in yield, poor agricultural technology, and proper fertilization. Insect pollinators must be flown by specific species of pollinators, and their importance for the seed management can be precisely determined on the basis of pollen analysis [64,67]. Red clover combines both the appropriate flowering time in the 
beekeeping season and a high pollen yield (from 29.7 to $202 \mathrm{~kg} \cdot \mathrm{ha}^{-1}$ ) [35,54], depending on the year, as well as a high foraging intensity of Apis mellifera and the simultaneous presence of pollen pickers on the flowers.

Another way to increase the fertility of clover seeds is to try to improve the morphology of flowers and ways to make them more attractive to bees and bumblebees. Breeders strive to breed short-tube clover varieties that nectar abundantly and at the same time are highly fertile. Such clover would probably be pollinated by short-lingual bumblebee species Bombus terrestris (L.) and B. luceruni (L.), which had previously gnawed at the flower tubes from the side to get nectar, and thus did not fulfill the role of pollinators $[31,63,67,68]$. A honeybee with a longer tongue has not yet been bred, but work in this direction is more advanced. However, the methods of using the existing breeds of bees for pollination of red clover have been developed in detail [35].

From a practical point of view, the most important problem that limits the wider cultivation of red clover is the quality of the seed material, related to the hardness of the seeds and their low germination capacity. Previous attempts were made to solve the physiological and morphological determinants of seed hardness with little success $[57,64,67]$. They mainly result from the specific structure of the red clover seed coat and its specific mechanical properties. The thick-walled layer of Malphi cells is practically impermeable to water during germination [53]. Attempts were made to increase the germination capacity of seeds of this species by applying mechanical and chemical scarification of seeds, subjecting them to low and high temperature stress, as well as laser and ultrasound biostimulation [4,5,67-69]. The mechanical features of the seeds testify to their suitability as seed material, but also to the possibility of their use in processing. Hard seeds are of poorer seed quality and result in higher processing costs $[68,70,71]$. Proper management of seed plantations and their collection, storage, and treatment before sowing significantly facilitates the germination process, and their processing is aimed at increasing the biological availability of substances or inactivating chemical compounds limiting sowing value.

\section{Conclusions}

The use of the 'Pollinus' attractant significantly increased seed yield, thousand-seed weight, and seed germination capacity. The best effects of attractant application were obtained when the preparation was applied twice, in stages 60 and 65 , on the $99^{\circ} \mathrm{BBCH}$ scale, compared to the control object. Therefore, it can be recommended for wide agricultural practice to perform two treatments with this preparation in the cultivation of red clover for seeds: the first at the beginning of flowering, when about $10-15 \%$ of flowers are open, the second in full flower, when about $90 \%$ of flowers are fully open. Using the preparation "economically", only once during full flowering, at a dose of $1 \mathrm{dm} \mathrm{ha}{ }^{-1}$, also allows to obtain a beneficial effect in the form of increasing the seed yield and its structure. Under the influence of plant biofortification with boron and molybdenum, the seed yield increased, their germination capacity increased, and the number of seeds infected with fungal pathogens and germinating abnormally decreased, as well as the number of 'hard' seeds. The germination capacity of red clover seeds was closely related to the share of hard, normally, and abnormally germinating seeds and seeds infected with fungal diseases. The second harvest date turned out to be the most favorable, both in terms of agriculture (the highest seed yield, the best its quality) and entomological and beekeeping factors that favor leaving for seeds, in temperate climate conditions, the second cut of clover, when most of the honey plants finish flowering. The meteorological conditions in the years of the research were decisive in the greatest extent about the yield of seeds and their quality. Optimal humidity and thermal conditions during the growing season of 2014 contributed to the collection of the highest seed yield from the seed swath; while the drought in the period of flowering and setting seeds limited the yield-generating possibilities of red clover and contributed to the deterioration of the seed quality. The high, potential yield of clover seeds was favored by the average daily air temperature during the growing season, oscillating between 14.6 and $15.0^{\circ} \mathrm{C}$ and the sum of rainfall above $330-350 \mathrm{~mm}$, Adaptation 
of seed red clover to less favorable conditions for growing may require increasing the amount of water retained in soil by introducing infrastructure for small water retention and denaturalization of habitats.

Author Contributions: Conceptualization, M.Ć. and A.P.; methodology, M.Ć. and B.S.; software, P.P.; validation, B.S. and M.Ć.; formal analysis, A.P. and B.S.; investigation, A.P.; resources, P.P. and A.P.; data curation, A.P. and M.Ć.; writing-original draft preparation, A.P. and B.S.; writing-review and editing, M.Ć. and B.S.; visualization, A.P., B.S. and P.P.; supervision, B.S.; project administration, M.Ć.; funding acquisition, B.S. All authors have read the CRediT taxonomy. Authorship is limited to those who have contributed substantially to the work reported. All authors have read and agreed to the published version of the manuscript.

Funding: This research received no external funding.

Institutional Review Board Statement: Not applicable.

Informed Consent Statement: Not applicable.

Data Availability Statement: All Authors declare that there are no conflict of interest.

Conflicts of Interest: The authors declare no conflict of interest.

\author{
Abbreviations \\ $\mathrm{BBCH}$ Biologische Bundesanstalt, Bundessortenamt und CHemische Industrie-Federal Biological \\ Institute, Federal Plant Variety Office and Chemical Industry \\ ISO International Organization for Standardization \\ MTS mass of thousand seeds \\ PN Polish Standards
}

\title{
References
}

1. Gaweł, E. Selected issues of the technology of growing small-seed legumes. Stud. Rep. IUNG-PIB 2014, 41, 39-56. (In Polish)

2. Harasim, J.; Harasim, A. Productivity of pasture mixtures with white clover (Triforium repens L.) in various habitat conditions. Monogr. Sci. Pap. IUNG-PIB 2010, 26, 1-65. (In Polish)

3. Staniak, M.; Kowalska, I.; Czopek, K.; Steppień, A. Comparison of the growth and development of selected species and families of clover (Trifolium sp.) In terms of their agricultural use. Łakkarstwo Polsce/Grassl. Sci. Pol. 2017, 20, 163-181. (In Polish)

4. Żuk-Gołaszewska, K.; Wanic, M.; Orzech, K. The role of catch crops in the field plant production-A review. J. Elem. 2019, 24, 575-587. [CrossRef]

5. Wilczek, M.; Ćwintal, M. The effect of pre-sowing laser stimulation of seeds and feeding with microelements (B, Mo) on the yield of seed-bearing tetraploid red clover in four-year use. Acta Agroph. 2011, 17, 207-217. (In Polish)

6. Mayer, D.F.; Britt, R.L.; Lunden, J.D. An evaluation of Bee scent as a honey bee attractant. Good Fruit Grow. 1989, $129,41-42$.

7. Winston, M.L.; Slessor, K.N. Application of queen honey bee mandibular pheromone for bee keeping and crop pollination. Bee World 1993, 74, 111-128. [CrossRef]

8. Ambrose, J.T.; Schultheis, J.R.; Bambara, S.B.; Mangum, W. An evaluation of selected commercial bee attractants in the pollination of cucumbers and watermelons. J. Apic. Res. 1995, 135, 267-272.

9. Janas, R.; Grzesik, M. Non-chemical methods of improving the quality and health of vegetable seeds. In Proceedings of the XIII National Scientific Conference, Zakopane, Poland, 27-30 November 2017; pp. 73-76, ISBN 83-891172-87-9.

10. Naik, D.G.; Dandge, C.; Puntambekar, H. Swertia densifolia leaf extract as a dose-dependant attractant or repellent for Apis florae. J. Apic. Res. 2007, 46, 15-18. [CrossRef]

11. Naik, D.G.; Dandge, C.; Puntambekar, H.; Patil, T. Attractant and repellent properties of Swertia densifolia leaf extract towards Apis cerana indica. J. Apic. Res. 2005, 44, 116-118. [CrossRef]

12. Mayer, D.F.; Johansen, C.A. Field evaluation of chemical pollinator attractants on tree fruits. Am. Bee J. 1982, 122, $287-289$.

13. Mcgourty, M.A. Field Evaluation of “Bee-Here a Pheromone Based Forage Attractant for Honey Bees, Aphis mellifera L., Applied to Red Clover, Trifolium pratense L. Master's Thesis, Oregon State University, Corvallis, OR, USA, 1992.

14. Viraktamath, S.; Patil, R.K. Preliminary studies on the influence of bee attractants on bee visitation and yield parameters of sesamum, Sesamum indicum L. Indian Bee J. 1999, 61, 55-58.

15. Malerbo-Souza, D.T.; Nogueira-Couto, R.H.; Couto, L.A. Lures and pollination of honeybees in sweet orange, Citrus sinensis (L.) Osbeck, var. Pera-Rio. J. Ven. Animal Toxins 2004, 10, 144-153. [CrossRef]

16. Mrówczyński, M. (Ed.) Integrated protection of agricultural crops. In Basics of Integrated Protection; State Agricultural and Forest Publishing House: Poznań, Poland, 2013; Volume I, p. 153. (In Polish) 
17. Strażyński, P.; Gawel, E.; Horoszkiewicz-Janka, J.; Korbas, M.; Jajor, E.; Krawczyk, R.; Kierzek, R.; Mrówczyñski, M.; Pruszyñski, G.; Matysiak, K.; et al. Methodology of Integrated Protection and Production of Clovers; Strażyński, P., Ed.; Institute of Plant Protection-National Research Institute: Poznań, Poland, 2016; ISBN 978-83-64655-11-1. (In Polish)

18. Mocek, A.; Drzymała, S. Origin, Analysis and Classification of Soils; Publishing House of the University of Life Sciences: Poznan, Poland, 2010; p. 418. ISBN 978-83-7160-586-4. (In Polish)

19. Ryzak, M.; Bartmiński, P.; Bieganowski, A. Methods of determination of granulometric distribution of mineral soils. Acta Agroph. 2009, 175, 97. (In Polish)

20. Bartmiński, P.; Krusińska, A.; Bieganowski, A.; Ryzak, M. Preparation of soil samples for the measurement of particle size distribution. Ann. Soil Sci. 2011, 62, 9-15.

21. KQ/PB-75 Version 04 from March 26, 2018. Particle Size Distribution in the Range of Particles (0.02-2000) $\mu \mathrm{m}$ Range (0.01-99.99), Laser diffraction method. Scope of accreditation No AB 1186. Available online: file:/ / C:/DANE/Pobrane/AB\%201186\%20(2) .pdf (accessed on 13 January 2021). (In Polish).

22. ISO 10390: 2005. Soil quality-Determination of pH. Available online: https://www.iso.org/standard/40879.html (accessed on 13 January 2021).

23. KQ/PB-34 Version 05 of 01.07.2014. Organic Carbon Content. Scope of accreditation No AB 1186. Available online: file:///C: /DANE/Pobrane/AB\%201186\%20(3).pdf (accessed on 13 January 2021). (In Polish).

24. Kappen, H. Die Bodenazidität; Springer: Berlin/Heidelberg, Germany, 1929; pp. 169-170.

25. Skjemstad, J.O.; Gillman, G.P.; Massis, A.; Spouncer, L.R.; Leonie, R. Measurement of the exchange capacity of the cationic fraction of organic matter from soils using the modified compulsive exchange method. Soil Sci. Soc. Am. J. 2008, 39, 926-937. [CrossRef]

26. Jaworska, H.; Kobierski, M.; Dabkowska-Naskręt, H. Cationic exchange capacity and content of exchangeable cations in lessive soils of different grain size. Ann. Soil Sci. 2008, 59, 84-89. (In Polish)

27. PN-R-04022: 1996 + AZ1: 2002. Chemical and Agricultural Analysis of Soil. Determination of Available Potassium in Mineral Soils; Polish Committee for Standardization: Warsaw, Poland, 2002. (In Polish)

28. PN-R-04017: 1992. HCl Soluble Copper Content. in Mineral Soil; Polish Committee for Standardization: Warsaw, Poland, 1992. (In Polish)

29. PN-R-04019: 1993. HCl-Soluble Manganese Content in Mineral Soil; Polish Committee for Standardization: Warsaw, Poland, 1993. (In Polish)

30. PN-R-04021: 1994. HCl-Soluble Iron Content in Mineral Soil; Polish Committee for Standardization: Warsaw, Poland, 1994. (In Polish)

31. PN-R-04018: 1993. HCl-Soluble Boron Content in Mineral Soil; Polish Committee for Standardization: Warsaw, Poland, 1993. (In Polish)

32. PN-R-04020: 1994 + AZ1: 2004. Chemical and Agricultural Analysis of Soil; Polish Committee for Standardization: Warsaw, Poland, 2004. (In Polish)

33. PN-R-04023: 1996. Chemical and Agricultural Analysis of Soil. Determination of Available Phosphorus Content in Mineral Soils; Polish Committee for Standardization: Warsaw, Poland, 1996. (In Polish)

34. Wilczek, M.; Ćwintal, M. Effect of the methods of additional feeding with microelements (B, Mo) on the yield structure and seed yield of red clover. EJPAU 2008, 11, 1-8. Available online: http:/ / www.ejpau.media.pl/volume11/issue4/art-05.html (accessed on 13 January 2021).

35. Wilczek, M.; Ćwintal, M. Possibilities of improving the seeding value of red clover seeds by applying pre-sowing laser stimulation. Acta Agroph. 2009, 14, 221-231.

36. ISTA. International Rules for Seed Testing. 2020. Available online: https://www.seedtest.org/en/ista-rules-2019-_content---1--3 410.html (accessed on 13 January 2021). (In Polish).

37. Ordinance of the Minister of Agriculture and Rural Development on the methods of sampling and storage period for seed material, evaluation of this material, template of the seed sampling protocol and preparation of documentation for the assessment of this material. J. Laws 2014. Available online: https:/ /www.prawo.pl/akty/dz-u-2014-1795,18150071.html (accessed on 13 January 2021). (In Polish).

38. Skowera, B. Changes in hydrothermal conditions in Poland (1971-2010). Fragm Agron. 2014, 31, 74-87. (In Polish)

39. SAS. Enterprise 4.2 Program SAS/STAT ${ }^{\circledR}$ 9.2. Users Guide; SAS Institute Inc.: Cary, NC, USA, 2008.

40. Laudański, Z.; Mańkowski, D.R. Planning and statistical reasoning in agricultural research. In Plant Breeding and Acclimatization Institute (IHAR); National Research Institute: Radzików, Poland, 2007; p. 142.

41. Koronacki, J.; Ćwik, J. Statistical Learning Systems; Scientific and Technical Publishing House: Warsaw, Poland, 2005.

42. WRB. World Reference Database for Soil Resources. 2014. Available online: http:/ /www.fao.org/3/a-i3794e.pdf (accessed on 13 January 2021).

43. Marcinek, J.; Komisarek, J. Systematics of Polish Soils; Marcinek, J., Komisarek, J., Eds.; Publishing House “Wieś Jutra”: Warsaw, Poland, 2011; Volume 62, 193p.

44. Nawrocki, S. Fertilization Recommendations. Part I. Limit Numbers for the Evaluation of the Content of Macro-and Micronutrients in Soils; Works of Scientific Publishers IUNG: Puławy, Poland, 1991; p. 34.

45. Tomić, D.; Stevović, V.; Đurović, D.; Stanisavljević, R. The use of boron in the production of red clover (Trifolium pratense L.) seeds. J. Agric. Food Res. 2015, 54. [CrossRef] 
46. Banaszak, J. Information on the fauna of bees (Apoidae) in Poland in unpublished master's theses. Fragm Faun. 1985, 29 , 368. (In Polish)

47. Jabłoński, B. Agronomic and beekeeping value of short-tube populations of red clover (Trifolium pratense L.). J. Apicult. Sci. 2001, $45,37-50$.

48. Borański, M.; Kołtowski, Z.; Teper, D. Assessment of the Biodiversity of Wild Pollinating Insects and for Honey Flow in the Areas of Intensive Agricultural Cultivation. 2018. Available online: http://www.inhort.pl/files/program_wieloletni/PW_2015_2020_ IO/spr_2018/Boranski_2018_Raport_owady_dzikie_zadanie_4.2.pdf (accessed on 13 January 2021). (In Polish).

49. Semkiw, P. The Beekeeping Sector in Poland in 2019; Institute of Horticulture: Puławy, Poland, 2019; p. 12.

50. Potts, S.G.; Biesmeijer, K.; Bommarco, R.; Brezze, T.D.; Carvalheiro, L.G.; Franzén, N.; González-Varo, J.P.; Holzschuh, A.; Kleijn, D.; Klein, A.; et al. Status and Trends European Pollinators. Key Findings from the STEP Project; Pen Soft Publishers: Sofia, Bulgaria, $2015 ; 72 p$.

51. Regulation (EU) No 1308/2013 of the European Parliament and of the Council of 17 December 2013 Establishing a Common Organization of the Markets in Agricultural Products and Repealing Council Regulations (EEC) No 922/72, (EEC) No 234/79, (EC) No 1037/2001 and (EC) No 1234/2007. Available online: http:/ / data.europa.eu/eli/reg/2013/1308/2019-01-01 (accessed on 13 January 2021).

52. Report from the Commission to the European Parliament and the Council on the Implementation of Apiculture Programs. 2019. Available online: https:/ / ec.europa.eu/info/sites/info/files/food-farming-fisheries/animals_and_animal_products/ documents / report-implementation-measures-apiculuture-sector_2019-12-17_en.pdf (accessed on 13 January 2021).

53. Nithya, C.; Viraktamath, S.; Vastrad, A.S.; Palakshappa, M.G. Influence of indigenous bee attractants in enhancing pollination and yield of sesame, Karnataka. J. Agric. Sci. 2012, 25, 537-539.

54. Wilczek, M.; Ćwintal, M. Quality of diploid and tetraploid red clover on the background of varied mineral fertilization. Ann. UMCS Sec. E 2004, 59, 613-620.

55. Kotecki, A.; Janeczek, E. Wpływ nawożenia mikroelementami na gromadzenie składników mineralnych przez fasolę zwyczajną. Zesz. Probl. Post. Nauk Roln. 2000, 471, 353-360. (In Polish)

56. Kaiser, B.A.; Gridley, K.L.; Brady, J.N.I.; Phillips, T.S.; Tyerman, S.D. The role of molybdenum in agricultural plant production. Invited review. Ann. Bot. 2015, 96, 745-754. [CrossRef]

57. Starck, Z. Ion uptake and distribution. In Plant Physiology; Jan, K., Stanisław, L., Eds.; State Scientific Publishers: Warsaw, Poland, 2002; pp. 259-271. ISBN 83-01-13753-3. (In Polish)

58. Starck, Z. Plant physiology: How was yesterday, how is today, and what to include tomorrow? Cosmos. Probl. Biol. Sci. 2014, 63, 569-589. (In Polish)

59. Grzyś, E. The role and importance of micronutrients in plant nutrition Zesz. Probl. Post. Nauk Roln. 2004, 502, 89-99. (In Polish)

60. Kalbarczyk, R. Thermal and precipitation conditions and potato yielding in Poland. Ann. Univ. Mariae Curie-Skłodowska Sec. E 2003, 58, 35-44. (In Polish)

61. Kołodziej, J. Forming of climatic water balance in Poland in the years 1981-2000. Infrastruct. Ecol. Rural Areas $2008,5,85-97$.

62. Żuk-Gołaszewska, K.; Majewska, K.; Gołaszewski, J. Mechanical properties of single red clover seeds. Acta Agroph. 2011, 17, 229-239. (In Polish)

63. Denisow, B. Pollen Production of Selected Ruderal Plant Species in the Lublin Region; Univ Plant Sciences in Lublin Press: Lublin, Poland, 2011; Volume 351, p. 86. (In Polish)

64. Przybylska, A.; Ćwintal, M.; Brodny, J. Natural and agrotechnical conditions of growing red clover for seeds. In Agrotechnics of Cultivated Plants; Scientific Monograph; Institute of Economics and Technology: Legnica, Poland, 2015; p. 11. ISBN 978-83-9438611-5. (In Polish)

65. Sabrosky, B.; Kołtowski, Z. Honey-bearing plants for enriching bee hives. Beekeeping 2003, 54, 16-17. (In Polish)

66. Martínková, J.; Šmilauer, P.; Mihulka, S.; Latzel, V.; Klimešová, J. Impact of damage on aging of the whole plant: Experiment with two germinating species of Barbarea. Ann. Bot. 2016, 117, 667-679. [CrossRef] [PubMed]

67. Żuk-Gołaszewska, K. UV-B Radiation, in UV-B Radiation: From Environmental Stressor to Regulator of Plant Growth; Singh, V.P., Singh, S., Prasad, S.M., Parihar, P., Eds.; John Wiley \& Sons, Ltd.: Chichester, UK, 2017. [CrossRef]

68. Müller, M.; Siles, L.; Cela, J.; Munné-Bosch, S. Perennial young: Seed production and quality in controlled and natural Cistus albidus populations reveal compensatory mechanisms that prevent aging in terms of seed yield and viability. J. Exp. Bot. $2013,65$. [CrossRef]

69. Noble, D.; Jablonka, E.; Joyner, M.J.; Müller, G.B.; Omholt, W.S. Evolution is evolving: Physiology returns to the center. J. Physiol. 2014, 592, 2237-2244. [CrossRef] [PubMed]

70. Ćwintal, M.; Sowa, P.; Goliasz, G. Assessment of the possibility of improving the sowing value of red clover seeds by using pre-sowing laser stimulation. Influence of microelements (B, Mo) and laser stimulation on sowing value of red clover seeds. Acta Agroph 2010, 15, 65-76.

71. Banaszak, J.; Cierzniak, T. Economical effects of arable crops pollination by honey bee and wild bees (Apoidea). KOSMOS 1995, 44, 47-61. (In Polish) 